\title{
Revision of annulated orthoceridan cephalopods of the Baltoscandic Ordovician
}

\author{
Björn Kröger ${ }^{*, 1} \&$ Mare Isakar**,2 \\ ${ }^{1}$ Björn Kröger, Museum für Naturkunde der Humboldt-Universität, Invalidenstraße 43, D-10115 Berlin, Germany \\ 2 Mare Isakar, University of Tartu, Tartu Ülikool, Geoloogiamuuseum, Vanemuise 46, EST-51014 Tartu, Estonia
}

Received 31 January 2005, accepted 30 September 2005

Published online 01. 02. 2006

With 12 figures

Keywords: Cephalopoda, Orthocerida, Middle Ordovician, Late Ordovician, Estonia.

\begin{abstract}
The annulated orthoceridans of the Middle and Late Ordovician of Baltoscandia are described and their systematic frame is revised. The revision of these nautiloids, which are part of the Orthocerida and Pseudorthocerida, is based on the investigation of characters of the septal neck, the siphuncular tube, and the apex. An unequivocal terminology of these characters is suggested and applied. The shape of the septal neck and the siphuncular tube are described for the first time in Palaeodawsonoceras n. gen., Striatocycloceras n. gen., Dawsonoceras fenestratum Eichwald, 1860, and Gorbyoceras textumaraneum (Roemer, 1861). Ctenoceras sweeti $\mathrm{n}$. sp. is erected. The apex of Dawsonoceras barrandei Horný, 1956 is figured and described for the first time. The distribution of the character states of the apex and the septal neck support the emendation of the families Orthoceratidae, Dawsonoceratidae, and Proteoceratidae. The analysis shows also that the families Kionoceratidae, and Leuroceratidae must be refused because they represent not natural groups. However, it is also shown that the present knowledge is not sufficient to establish an unequivocal classification of the Middle, and Late Ordovician annulate cephalopods.
\end{abstract}

Schlïsselwörter: Cephalopoda, Orthocerida, Mittleres Ordovizium, Spätes Ordovizium, Estland.

\section{Zusammenfassung}

Die orthoceriden Cephalopoden des Mittleren bis Späten Ordoviziums im Baltoskandium werden beschrieben und revidiert. Die Revision dieser Cephalopoden, welche zu den Orthocerida und Pseudorthocerida gehören, stützt sich auf die Untersuchung der Apikalenden, der Septalduten und der Form der Siphonalröhre. Eine eindeutige Terminologie für diese Merkmale wird vorgeschlagen und angewandt. Die Form der Septalduten und der Siphonalröhre von Palaeodawsonoceras n. gen., Striatocycloceras n. gen., Dawsonoceras fenestratum, Eichwald, 1860 und Gorbyoceras textumaraneum (Roemer, 1861) wird erstmals beschrieben. Die Art Ctenoceras sweeti n. sp. wird aufgestellt. Der Apex von Dawsonoceras barrandei Horný, 1956 wird erstmals beschrieben und dargestellt. Die neu gefundenen Merkmale stützen eine Emendation der Familien Orthoceratidae, Dawsonoceratidae und Proteoceratidae. Es wird daher dafür plädiert, die Familien Kionoceratidae (Hyatt, 1900) und Leuroceratidae (Sweet, 1964) nicht mehr zu verwenden, da diese keine natürlichen Gruppen repräsentieren. Die Untersuchung zeigt aber auch, dass es derzeit noch nicht möglich ist die annulaten Cephalopoden des Mittleren und Oberen Ordoviziums zweifelsfrei zu klassifizieren.

\section{Introduction}

Orthoceridans are the most common cephalopods from the beginning of the Middle Ordovi- cian until the Early Devonian. The classification of these cephalopods is very difficult because of the simplicity of their conchs. The characters that are visible on the surface of orthoceridan

\footnotetext{
* Corresponding author: e-mail: bjoekroe@gmx.de

** E-mail: mi@ut.ee
} 
conchs repeatedly occur in identical combinations.

The internal characters are few; only the shape of the septal neck and the shape of the connecting ring were subjected to significant variability during evolution. Surprisingly, the shapes of the apical shell portion of longicones are strongly differentiated down to the species level (Ristedt 1968; Kröger \& Mapes 2004). However, these apices have often been overlooked with regard to orthoceridan classification.

Early classifications only considered surficial shell features that where traditionally labelled with generic names. At the end of the $19^{\text {th }}$ Century, three orthoceridan genera were established: the smooth Orthoceras Bruguière, 1789, the transversely striated Geisonoceras Hyatt, 1884, and the annulated Cycloceras McCoy, 1844. Three additional genera were characterised by the combination of annulations, as well as transverse and longitudinal elements of ornamentation: Dawsonoceras Hyatt, 1884 includes, by original description, forms that are annulated and show longitudinal ridges mainly in juvenile stages. Spyroceras Hyatt, 1884 includes, by original description, longitudinally ridged forms that show annulation mainly in later growth stages, and Kionoceras Hyatt, 1884 includes, by original description, longicones with prominent longitudinal ridges that lack annulations.

In a series of papers, Flower $(1939,1941,1942$, 1943, 1962) established the consideration of the shape of the septal necks for the orthoceridan classification. Flower showed that the septal neck shape is a strongly conservative and stable character in these cephalopods. He also demonstrated that the pattern of shell ornamentation in orthoceridans is repeatedly subjected to homeomorphism. Unfortunately, with regard to the classification of Late Ordovician and Silurian cephalopods of the northern hemisphere, the internal features of much of the cephalopod material are often rather poorly preserved (e.g. the conchs from the Cincinnatian of Ohio, from the Niagara dolomites, or from the Late Ordovician carbonates of Estonia). Only few specimens show details of the siphuncle. Thus, many of the species that are described have been assigned to one of the traditional genera Orthoceras, Cycloceras, Dawsonoceras, Spyroceras, and Kionoceras, leaving no room for phylogenetic interpretations. Moreover, the vast majority of taxonomic work concerning early Palaeozoic orthoceridans was carried out prior to the early 1920 s by Foerste (1921, 1924, 1928a-c, 1932), Troedsson (1926), and Teichert (1930) who did not realize the importance of the septal necks and therefore gave no descriptions of them. A general revision of these taxa lacks until today.

The collection of a large quantity of material enhances the probability that internal and apical features will be discovered in orthoceridan fragments. During the last few years, we have investigated material stored in the palaeontological collections of Estonia and Germany and collected additional material during two field trips in 2002 and 2004. As a result, approximately 150 specimens of annulated orthoceridans from Baltoscandia are available for comparison and classification.

To our surprise, the vast majority of species of annulated orthoceridans from Baltoscandia have already been described (Eichwald 1860; Schmidt 1858, 1861; Angelin \& Lindström 1880; Teichert 1930 ) or could be assigned to species that are known from North America (Hall 1847; Foerste 1932). Therefore, our contribution is restricted mainly to improve the knowledge of the internal and apical characters of the species in order to present a more realistic classification of these orthoceridans. Additionally, this investigation will contribute to the understanding of the general evolution of the orthoceridans in a time interval that is practically a blind spot in our knowledge of the cephalopod evolution.

\section{On nautiloid systematics}

Our paper focuses on annulated orthocones with (sub-) central siphuncles. Traditionally, these cephalopods have been subsumed within the Orthocerida. However, recent investigations by Kröger \& Mapes (2005) and Kröger (2006a) approve the idea of Barskov (1968) that the order Orthocerida represents a paraphyletic clade. Therefore, we accept the Pseudorthocerida Barskov, 1968 and the Orthocerida Kuhn, 1940 as real taxonomic entities. It is believed that the Pseudorthocerida are characterised by the presence of cyrtochoanitic septal necks and the lack of a cicatrix.

Orthocones that exhibit the character state cyrtochoanitic exclusively comprise forms with apices including a cicatrix, whereas the character state orthochoanitic (and achoanitic) includes only forms with apices lacking a cicatrix (Appendix 1). However, all known pseudorthoceridan apices belong to post Devonian taxa. Currently no apex of a Ordovician, Silurian, or Devonian pseudorthoceridan is known. This lack of data can be interpreted in two ways. (1) It could be 
construed that the Permian and Carboniferous taxa represent a particular higher taxon that did not exist before the Carboniferous, or (2) it could be assumed that, although existent, the Pseudorthocerida played a minor role in the preCarboniferous. We support the second hypothesis herein, because currently there is no evidence that would allow to conclude, that all preCarboniferous cyrtochoanites lack a cicatrix. And in fact, although cyrtochoanitic orthocones are present, they are clearly less common in most areas that expose pre-Carboniferous $\mathrm{Pa}$ laeozoic strata, except of the Actinocerida. This is especially the case for the Silurian orthoceridan limestones. Thus, we accept the presence of Pseudorthocerida in pre-Carboniferous strata because no convincing falsification of this hypothesis can be presented at the time.

In the last years the opinion prevailed that ellesmeroceridans, and primitive nautiloids in general, carried a spheroidal embryonic shell that lacked a cicatrix (Dzik 1981; Engeser 1996). By contrast, we follow the assumption herein that the presence of a cicatrix in Ordovician orthocones represents a plesiomorphic state because a cicatrix is also known within Oncoceratida, Discoceratida, Tarpyceratida (see e.g. Shimansky 1962; Barskov 1989). Kröger \& Mutvei (2005) demonstrated the close relationship between oncoceridans, discosoridans, tarphyceridans, and ellesmeroceridans by evidence of the muscle attachment scars. Several more characters, such as the position, dimension, and shape of the siphuncle, the shape of the body chamber, the structure of the siphuncular tubes give evidence for a very close relationship between oncoceridans, tarphyceridans and ellesmeroceridans. Within this framework the Orthocerida with their thin, central siphuncles, thin siphuncular tubes and spheroidal apices appear clearly as derived forms. Consequently, we treat the pseudorthoceridan Gorbyoceras as outgroup of our investigation.

It must be emphasized, that the outgroup determination of the Pseudorthocerida follows explicitly the purpose to highlight the polyphyly of the annulated orthoceridan nautiloids; it must neglect the relationshpis to the Oncocerida, Tarphycerida, Discosorida and Ellesmerocerida.

\section{Institutional abbreviations}

The institutions that store the material are:

AMNH American Museum of Natural History, New York, USA.
KIG LGU Musee Kafedry Istoricheskoi Geologii Leningradskogo Universiteta, Sankt

Petersburg.

MB.C. Cephalopod Collection in the Museum für Naturkunde, Berlin, Germany.

TUG University of Tartu, Museum of Geology, Tartu, Estonia.

GIT Institute of Geology at Tallinn University of Technology, Tallinn, Estonia.

SMF Naturmuseum Senckenberg, Frankfurt am Main, Germany.

UMPC University of Michigan, Museum of Paleontology, Ann Arbor, Michigan, USA.

UWR Instytut Geologii, Uniwersytet Wroclawski, Wroclaw, Poland.

\section{Material}

The material of more than 150 fragments of specimens was collected in a number outcrops of northern Estonia (see Appendix 2). These outcrops represent a succession of carbonates of the North Estonian Confacies belt at the northern flank of the Livonian Tongue (Fig. 1; see also Jaanusson 1976). The Estonian Ordovician sedimentary succession shows a total thickness of 70 to $180 \mathrm{~m}$ (Meidla \& Ainsaar 2004) and is divided in several regional stratigraphic units (Fig. 2; see Rõõmusoks 1970, 1983 for detailed description; Männil 1990; Meidla \& Ainsaar 2004 for recent compilations). The Middle and Late Ordovician Viru and Harju Series consists of a succession of carbonates that contains numerous phosphatic and limonitic omission horizons and locally a variable quartzitic terrigenous influx occurs at its base (Aseri to Uhaku Regional Stage). Accumulations of organic material and argillaceous beds dominate at the middle portion (Kukruse to lower Haljala Regional Stages) and micritic, bioclastic, argillaceous carbonates with locally intercalated bioherms are common at the top (Keila to Porkuni Regional Substages). Locally, horizons with fossil silicification (Haljala Regional Stage in north-east Estonia) or flint horizons (Porkuni Regional Stage in Porkuni north-central Estonia) occur and provide exceptional preservation of small macrofossils.

Several specimens have been collected from Pleistocene erratics of northern Germany and Poland. These erratic blocks mainly represent lithologies that are most resistant to erosion and weathering. Annulated orthoceridans within erratic

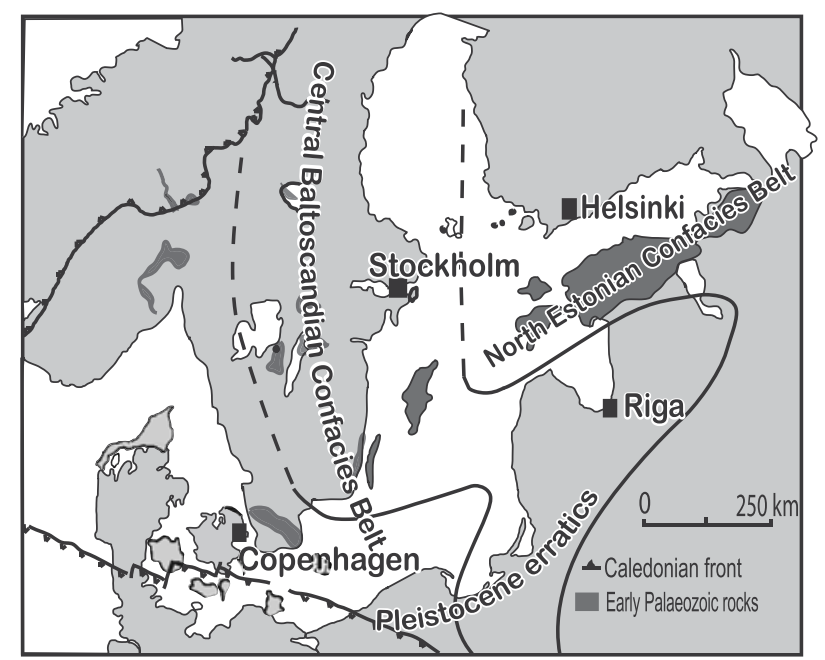

Fig. 1. Regional overview on the lower Palaeozoic of the Baltoscandian (after Jaanusson 1976) 


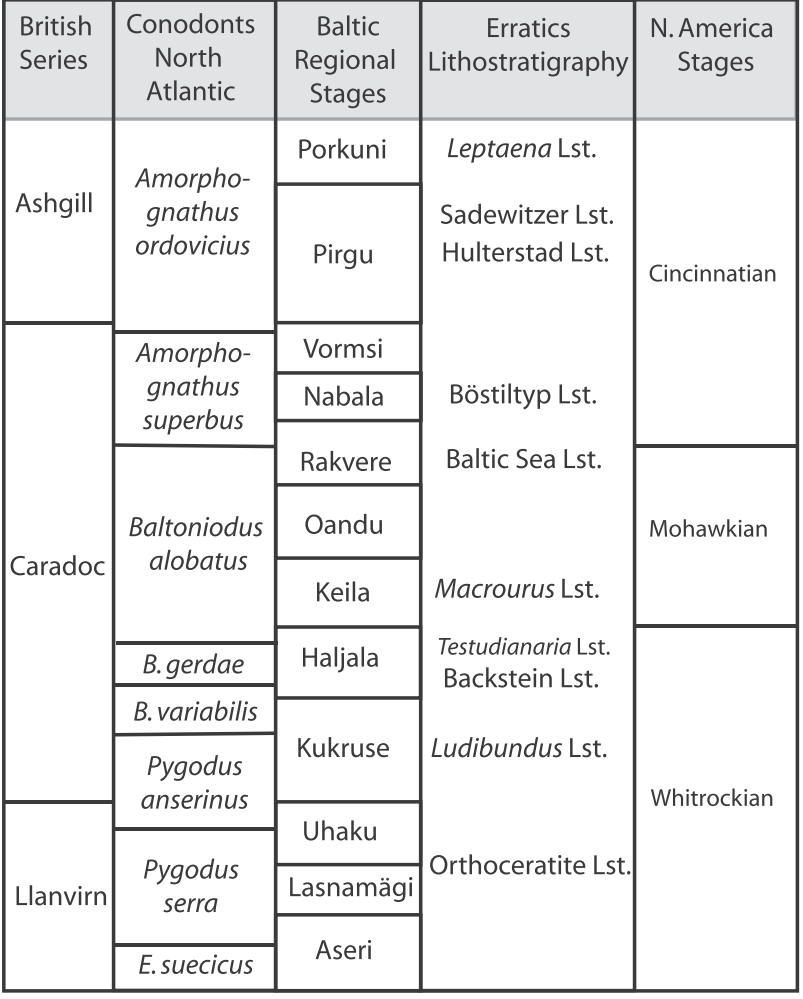

Fig. 2. Stratigraphical subdivision and correlation of Middle and Late Ordovician in Baltoscandia. Compiled after Männil (1990), Webby (1995) Maidla \& Ainsaar (2004), and Neben \& Krüger (1973).

blocks of Middle or Late Ordovician age are known from the Upper Grey Orthoceratite Limestone, from the Backstein Limestone, and from the Sadewitz Limestone (Fig. 2). The lithology and faunal content of the erratic blocks has been investigated throughout the past two centuries. A review of the investigations particularly of the Orthoceratite Limestone is given by Kröger (2004). Roemer (1861) published a detailed monograph of the fauna of the erratic limestones of Sadewitz (now Zawidowice, near Olesnica, Poland). A compilation of the palaeontology of the Backstein Limestone is given by Neben \& Krüger (1971, 1973). The investigated species occur in limited time intervals, providing a rough biostratigraphic tool (Fig. 3).

Several collectors have compiled specimens during the last two centuries. The main contributors are: H. Stumbur (at reposition of the GIT and TUG), K. Orviku (at reposition of the GIT), M. Isakar and B. Kröger (at reposition of TUG), F. Damer (at reposition of the MB.C.), and D. Oswald (at reposition of the MB.C.).

\section{Terminology}

Terminology of the nautiloid morphology is often not unequivocal, because different authors refer to the same terms for different meanings. Therefore, it is necessary to define some of the terms used herein.

An apex is termed "large" when the initial $5 \mathrm{~mm}$ are more than $2 \mathrm{~mm}$ in cross-section diameter. An apex is called "acute" when cross-section diameter of the initial interval of the shell increases roughly constantly in dimension; it is called "blunt" when the cross-section diameter grows logarithmically at the apical $5 \mathrm{~mm}$.

The septal neck is the bending of the septum at the margin of the septal perforation. The term siphuncular tube is

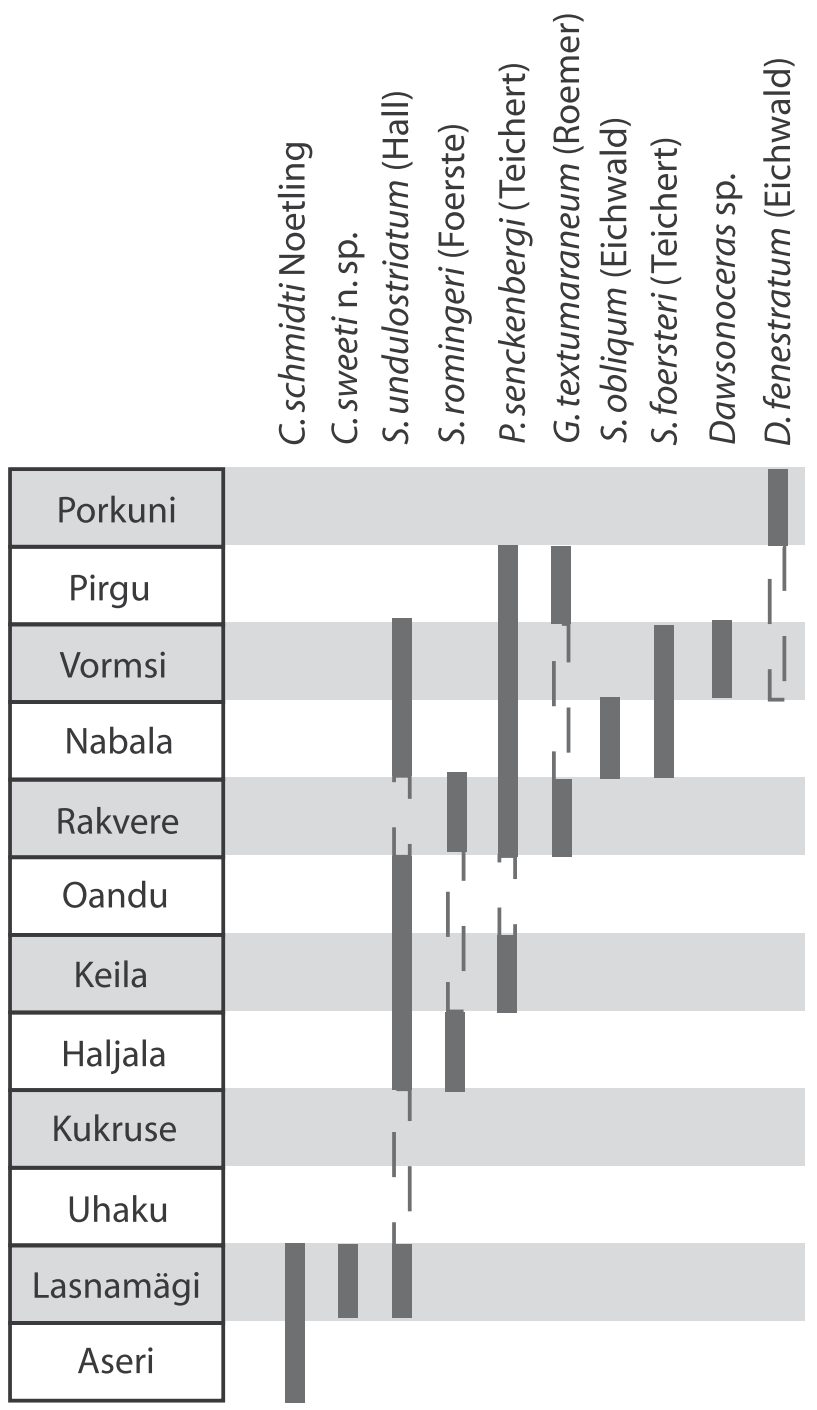

Fig. 3. Stratigraphic range of annulated orthocones of Estonia and the erratics of north central Europe in the frame of the Baltic Regional Stages.

used synonymous with the term connecting ring referring to the conchiolinic (sometimes calcified) prolongation of the septal neck. The connecting ring consists of segments spanning the margin of the septal neck apicad toward the next septal perforation. When using the terminology of septal neck morphology we follow Flower (1964). However, the problem in Flower's terminology is that it not distinguishes properly between the length of the septal neck and its shape. Thus, an orthochoanitic septal neck may be refer to a hemichoanitic septal neck, or holochoanitic respectively. We include the length of the septal neck within the definition of the terms herein in order to crate an unambiguous terminology.

Achoanitic septal necks are virtually absent septal necks. Thus the term refers to a septal perforation that is only very slightly bent or not bent.

Loxochoanitic septal necks are pointing obliquely inward and backward toward the siphuncle (curvature of the septal neck $<90^{\circ}$ ).

Suborthochoanitic septal necks are short and scarcely recurved, "lying on the tenuous boundary between orthochoanitic and cyrtochoanitic" (Flower 1964, p. 16). Thus in suborthochoanitic septal necks the tip of the septal margin in cross section points toward the external shell, phasing out toward a slightly expanded siphuncular tube. The difference 
between suborthochoanitic septal necks and cyrtochoanitic septal necks is not clearly defined by Flower (1964) and Teichert (1964). We refer to suborthochoanitic necks in the case at which the curvature of the septal neck is $>90^{\circ}$ and $<180$. The experience of the authors shows that septal necks with a curvature between $90^{\circ}-180^{\circ}$ are in almost all cases shorter than $1 / 10^{\text {th }}$ of the length of the siphuncular segment. Thus, suborthochoanitic septal necks are very short septal necks.

Orthochoanitic septal necks point parallel to the growth axis, and phasing out toward a tubular siphuncular tube (curvature of the septal neck $90^{\circ}$ ). Orthochoanitic septal necks are shorter than the half of the siphuncular segment.

Cyrtochoanitic septal necks are recurved, they phase out to an expanded siphuncular tube (curvature of the septal neck $>180^{\circ}$ ). The length of cyrtochoanitic septal necks is usually more than one tenth of the siphuncular segment but usually not exceeds the half of the siphuncular segment.

Hemichoanitic septal necks point twoard the growth axis like orthochoanitic septal necks. But hemichoanitic septal necks are long, comprising more than the half of the length of a siphuncular segment.

Holochoanitic septal necks are those septal necks that are longer than the distance between two successive chambers. Holochoanitic septal necks point always in direction of the growth axis.

\section{Methods}

Any classification of orthocone nautiloids suffers from the extraordinarily low number of characters that are available for clade construction. Moreover, these characters are often likely to represent homoplasy. The characters that are available for classification in Ordovician nautiloids are the cicatrix (absence/presence), the general shape of the apex, the shape of the septal neck and the ornamentation. Endosiphuncular or endocameral deposits are lacking in the investigated taxa. We use a cladistic argumentation in order to formalise the relationship of the classification scheme of the nautiloids in discussion. The merit of this method is a more transparent process of the classification. However, because of the low number of characters that are available, the analysis reflect more the authors point of view rather than a neutral phylogenetic assumption. Crucial for our analysis is the evaluation of the individual characters for the classification. However, the value of the individual characters is developed from empirical knowledge that is beyond the scope of our investigation. Therefore, it is not possible to develope objective criteria that would allow defining specific values of weight for each character within the scope of our investigation. Consequently, we follow the practice to give all the observed characters the same value.

The cladistic method is based upon outgroup comparison. Therefore any cladistic classification must refer to a proper level of hierarchy. For example, the classification of Orthoceratidae must refer to a higher hierarchical level defining the plesiomorphic states shared by all Orthocerida. The Orthocerida, must refer to the next higher level, and so on. Because a complete cladistic scheme of all nautiloids is presently missing, we are in duty to define the outgroup of the clade observed within this study, a priori. Gorbyoceras serves for determination of the plesiomorphic state (outgroup). Thus, ingroup commonality of the absence of a cicatrix is assumed. The focus of this investigation lies on the Ordovician annulated, suborthochoanitic, and orthochoanitic orthocones. Therefore, the outgroup determination of Gorbyoceras of the Pseudorthocerida follows explicitly the purpose to highlight the relations of the genera that are investigated herein; it must neglect the diverse smooth Ordovician and Silurian orthoceridans.

\section{Characters of orthoceridan cephalopods}

Cicatrix - The absence or presence of the cicatrix is of very high value in classification of cochleate cephalopods (Kröger \& Mapes 2004). The cicatrix itself is merely a proxy of the relative dimension of the shell gland at time of initial secretion of the shell; it is tightly connected with the shape of the embryonic shell. If a cicatrix is present, the apex is usually acute and conical, if the cicatrix is absent the apex is spherical and blunt. However, rare exceptions exist from this rule. The absence or presence of a cicatrix divides the cochleate cephalopods into two groups that are consistent with higher-level classification. The only exception is the Orthocerida when referring to Sweet (1964), Balashov \& Zhuravleva (1962), and Dzik (1984). The offsplitting of the Pseudorthocerida Barskov, 1968 from the Orthocerida accounts for this inconsistency. We account the absence or presence of a cicatrix of very high value, so that the outgroup in our investigation is based on the a priori decision that an apex is present.

Apex shape - Coding a complex feature such as the apex shape in distinctive qualities is problematic because the borders of difference are not entirely known. Moreover, what makes the difference between "blunt" and "acute" can change considerably when changing the dimension of observation (e.g. magnification in a binocular). The terms "blunt" and "acute" are used within our paper within the dimension of the apical $5 \mathrm{~mm}$. This is a practice that is based purely of the observation of the dimension of apices of Ordovician orthoceridans. At the time no transitional morphologies are known between the two types of apex shape. Therefore, we consider this character from high value in our analysis.

Shape of septal neck - The shape of the septal neck is of high value in nautiloid classification; it seems to be an evolutionary relatively stable character in Palaeozoic nautiloids. However, the shape of septal neck is connected with the shape of the siphuncular tube, and thus, with some functional constraints related to buoyancy regulation (e.g. Kröger 2003). Therefore, a cyrtochoanitic septal neck is usually connected with an expanded siphuncle, a holochoanitic septal neck with a very large siphuncle. This observation shows that homeomorphy is likely in the septal neck shape. However, because of the lack of additional characters, the homoplasy of of sep- 
tal neck shape is very difficult to detect. The apex shape is a character that may help to detect homoplasy in septal necks in future. At present time, we simply rely on the septal neck shape as one of the most important characters for nautiloid classification. In primitive nautiloids (Late Cambrian, Early Ordovician) and within some early Palaeozoic orthoceridans the shape of the septal neck varies within ontogeny of a single specimen. However, the pattern of change is characteristic for each taxon. An exception from this rule represents the group Nautilida; there the variation of the septal neck shape is more complex and less valuable. In general, the classification of nautiloids referring to septal neck shape, turned out to be a very reliable source for classification since the papers of Teichert (1933) and Flower \& Kummel (1950).

Endosiphuncular and cameral deposits - The use of the shape of endosiphuncular and cameral deposits for classification is problematic, because the driving mechanisms for the development of deposits are only poorly understood, and the control over the mineralisation of the deposits varies strongly between the taxa. Moreover, the deposits develop successively during ontogeny, depending on the growth age. Thus, a single specimen may completely lack deposits or display very different deposit pattern in its different growth intervals. Historically, a practice has been established that accounts for the shape of deposits individually for specific taxa and for different ranks. However, in the context of our paper the deposits can be neglected because no significant deposits are found within the investigated taxa.

Ornament - The ornamentation traditionally served as prime source for the classification of orthoceridans (see above). This fact simply can be explained by the easy availability of the features of ornamentation in almost every specimen. However, very similar ornament exists in distant clades. The ornament of the Darriwillian endoceratidan Anthoceras vaginatum (Schlotheim, 1813) is almost identical to the Late Ordovician orthoceridan Striotocycloceras undulostriatum (Hall, 1847). Consequently, the ornamentation can have a systematic value only within a certain (restricted) taxonomic range. We consider the value of ornament for classification only within the generic range. When comparing higher taxa the consideration of characters of ornamentation results in absurd cladograms (compare e.g. Fig. 4B). Many Pseudorthocerida and
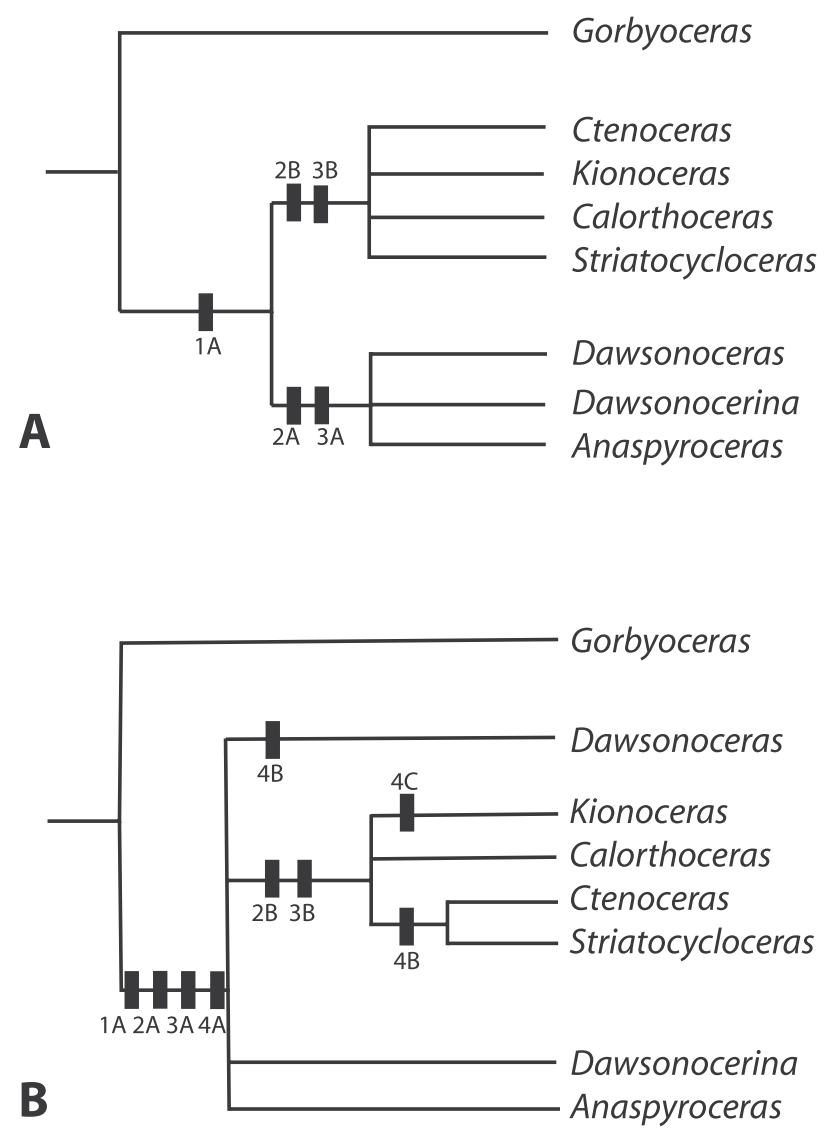

Fig. 4. Cladograms of nine orthoceridan and pseudorthoceridan nautiloids. The pseudorthocerid Gorbyoceras Shimizu \& Obata, 1935 serves for determination of the plesiomorphic state (outgroup). Thus, ingroup commonality of invariable, short septal necks and the absence of a cicatrix are assumed. A - Most parsimonious cladogram based on three characters. In this cladogram the ornamentation is considered to be from no value a priori, because of its high susceptibility for homeomorphy. The trees show two branches defined by the apomorphy of siphuncular necks shape, and length, and the apex shape, one includes all Orthoceratidae the other includes all Dawsonoceratidae. B - Cladogram based on four characters. Orthoceridans with short septalnecks appear as subclade of orthoceridans with dominant transversal ornamentation. See text for discussion. 1A - cicatrix absent. 2A - very short septal necks. 2B - orthochoanitic septal necks. 3A - large, bent, blunt apex. 3B - small, straight, acute apex. 4A - transversal ornamentation dominant. 4B - reticulate ornamentation. $\mathbf{4 C}-$ longitudinal ornamentation dominant.

Actinocerida display a transversal ornamentation. Including the ornamentation within a cladistic analysis at the ordinal level between Actinocerida, Pseudorthocerida and Orthocerida would result in a cladogram where the transversal ornamentation characterises at a very high level a clade with several subclades where this trait is lacking. Such a cladogram does not reflect any natural group.

Adult modifications - Following Riedl (1975) a burden, a word that signifies an inherited weight (the words "birth" and "burden", in 
German: "Geburt" and "Bürde", go back to the same indogermanic root), is defined as the responsibility that a character carries with respect to the function of a fertile organism. Characters with a high burden appear very high in the classification hierarchy because any phylogenetic change of such a character strongly changes the fertility of the organism. Characters with a low burden appear low in hierarchy and have large freedom to vary. The body chamber impressions of Orthoceras and Ctenoceras are restricted to these two genera, and they are very variable within these genera. Thus, they represent characteristic features of a very low burden and a very low value for the cladistic analysis.

\section{Systematic descriptions}

\section{Order Orthocerida Kuhn, 1940}

Emended diagnosis. Straight or curved with smooth or elaborately ornamented shells, with central or subcentral narrow siphuncle siphuncle that may be slightly expanded between the chambers. Siphuncular necks achoanitic, suborthochoanitic or orthochoanitic. Apex spherical, bowl-shaped or blunt, invariably without cicatrix.

Discussion. The emendation of the Orthocerida is necessary after investigations of the early growth stages of orthoceridans, pseudorthoceridans and actinoceridans that was carried out by Kröger (2006a) and Kröger \& Mapes (2006). There it can be shown that all known apices of orthocones that lack a cicatrix show achoanitic, suborthochoanitic or orthochoanitic septal necks. Contrarily, all cicatrix-carrying apices of orthocones that are known belong to cyrtochoanites (compare Kröger \& Mapes 2005). This investigations provide evidence that Pseudorthocerida and Actinocerida are sister groups with an acute apex that carries a cicatrix and cyrtochoanitic septal necks. The early growth stages of the Orthocerida are fundamentally different from these two orders invariably exhibit a spherical or bowl shaped blunt apex and short septal necks (see also Barskov 1989).

Until now, no complete apex of Orthoceras Bruguière, 1789 has been collected, but the smallest growth stages known from Orthoceras are very similar to closely related orthoceridans of the same age that are commonly known and that show spherical apices without cicatrix (compare Kröger 2006b). Additionally, we discovered in the 2004 field campaign an apex of an Orthoceras sp. at the top of the Lasnamägi Regional substage at Pliiku Ots at Väike Pakri (Estonia).
This apex was blunt, slightly spherical, and very similar in shape and dimension to that found in Archigeisonoceras (Kröger 2006b). Unfortunately, the single specimen was destroyed during preparation. It is therefore concluded that the Order Orthocerida must include the apex characters.

\section{Family Orthoceratidae McCoy, 1844}

Emended diagnosis. Orthocones with slender, central or subcentral, tubular or moderately expanded siphuncle. Septal necks suborthochoanitic or orthochoanitic, respectively. Shell smooth or annulated, with more or less well developed longitudinal and transverse ribs, ridges or combination of these. Ornamentation usually more well-developed in shell parts of later growth stages. Bowl-shaped apical shell small, straight, without cicatrix, without initial constriction, smooth or ornamented with transversal and longitudinal elements, but without annulations. Endosiphuncular and cameral deposits occur only in most apical chambers of quasi-mature specimens.

Stratigraphic and geographic occurrence. Late Early Ordovician to ?Late Devonian; worldwide.

Discussion. A comparison of all known orthochoanitic orthocone apices shows a common apex shape that is basically characterised by a bowl- shaped tip, the lack of a cicatrix and the lack of an initial constriction (Appendix 1). Therefore, apex shape and septal neck shape suggest evidence for a consistent taxonomic group, the monophylum Orthoceratidae.

With the emendation of the family Orthoceratidae, an explicit deletion of the subfamilies Orthoceratinae, Michelinoceratinae, Kionoceratinae, and Leurocyloceratinae that have been introduced by Sweet (1964), and are part of the Orthocerida, must be achieved. These subfamilies are considered remnants of the traditional nautiloidean classification that was based upon shell ornamentation. There is no evidence that these subfamilies represent real phylogenetic entities. Moreover, there is a morphological continuum of the ornamentation between the three.

Early attempts towards a classification of nautiloideans suffered from this phenomenon extraordinarily, because taxa such as Kionoceras Hyatt, 1884, Spyroceras Hyatt, 1884, and Cycloceras McCoy, 1844 originally and exclusively have been defined by their ornament.

The genus Kionoceras Hyatt, 1884, should include "... the longicones in which the longitudinal ridges are more prominent than the transverse striae" Hyatt (1884, p. 275). Subsequently, and in order to give consideration to the high variety of longicones with a prominent longitudi- 
nal ornamentation, Hyatt in Zittel (1900) erected a family Kionoceratidae.

A consequence of the erection of the family Kionoceratidae is the restriction of the focus of the genus Kionoceras. Foerste (1932) emended the genus. He faced the problem that the typical Kionoceras, Orthoceras doricum Barrande, 1877, includes at least two species, comprising forms that exhibit a transverse ornamentation of varying degree beneath a prominent longitudinal striation. Foerste (1932) selected only that variant of Orthoceras doricum figured by Barrande (1877, pl. 269: figs 1-13) lacking a transversal striation (or in that it is inconspicuous), focussing on the longitudinal striation only. The negligence of the variability of Kionoceras doricum, attributable to Foerste, creates a subsequent disregard of the variability of the entire morphological
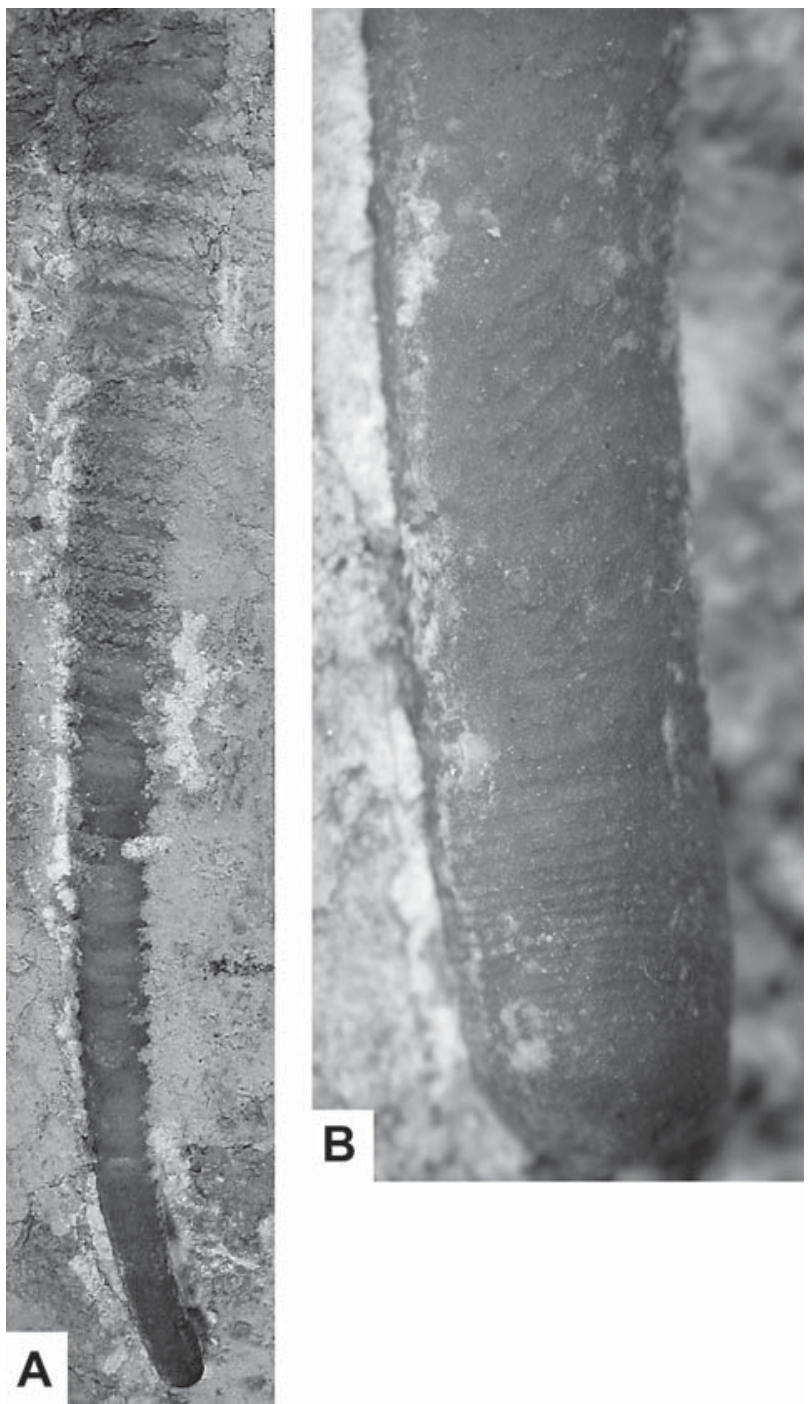

Fig. 5. Apex of Dawsonoceras barrandei Horný, 1956 , AMNH FI-21604 from Gotland. Note the blunt apex and the characteristic development of sculpture. Compare also the overall similarity of the apex shape with that of Dawsonocerina cealebs (Barrande, 1866). A $-\times 3 . \mathbf{B}-\times 5.6$. group of Silurian orthoceridans that includes the type material of Kionoceras.

This morphological group consists of Orthoceratidae, e.g. Kionoceras doricum, Calorthoceras pseudocalamiteum (Barrande, 1866) (Fig. 6A), and Bohemites aculeatum (Barrande, 1877), which are ornamented by longitudinal or transversal striae and costules, and a transversal annulation of varying degree that also may lack in some forms. Often, the annulation, as well as the longitudinal and the transversal ornament, occur only in more apical parts of the conch or each feature, respectively.

The commonalities of all these Orthoceratidae are orthochoanitic septal necks, the lack or strong suppression of endosiphuncular and cameral deposits, and a characteristic cap-shaped shell apex that lacks a cicatrix and a constriction of the initial chamber. Their apical shell is a simple, straight cone with a dimension of $1 \mathrm{~mm}$ at a
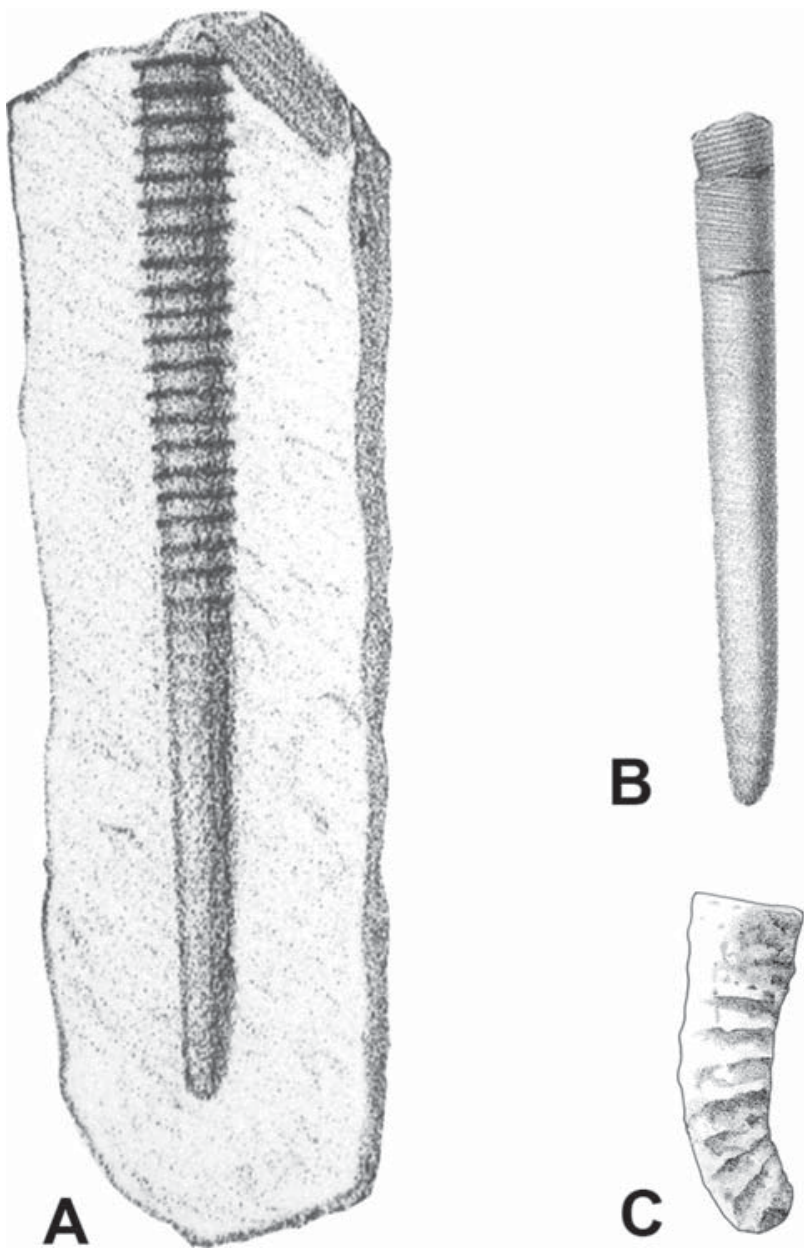

Fig. 6. Apex shape of Silurian annulated orthoceridans. Note the acute, straight apex in A, B, - and the blunt, bent apex in C. A - Calorthoceras pseudocalamiteum (Barrande, 1866). B - Columenoceras agassizi (Barrande, 1866). C - "Cyrtocycloceras" exiguum Chen 1981, no scale given in original Figure. A, B - from Barrande (1866), C - after Chen (1981), scale $\times 3$. 
conch length of $2 \mathrm{~mm}$ (Figs 5, 6; Barrande 1866, pl. 281: figs $12-13$, pl. 286: figs $14-16$, pl. 404: figs 1-19; Ristedt 1968, pl. 1: fig. 13). Therefore, the apex morphology, the shape of the septal neck, and siphuncle clearly indicate a close affinity to Michelinoceras (compare Ristedt 1968; Serpagli \& Gnoli 1977).

When Troedsson (1931) redescribed Orthoceras regulare Schlotheim, 1820, he emphasized the characteristic shell ornamentation of the genus consisting of faint longitudinal and transversal elements, which are principally the same as those in Kionoceras. Additionally, the enigmatic genus Ctenoceras Noetling, 1884 does not only share its characteristic three body chamber impressions with Orthoceras Bruguière, 1789, but also its characteristic shell ornament. In summary, the presence of longitudinal and transversal ornament seems to be a fundamental character in the entire Orthoceratidae, although it appears to be suppressed in some forms.

Therefore, there is no substantial reason for placing these genera into different higher taxa by diagnosis of the ornamentation only. The results of a phylogenetic analysis are summarised and illustrated in Fig. 4.

\section{Ctenoceras Noetling, 1884}

Type species. Ctenoceras schmidti Noetling, 1884.

Diagnosis. Slightly cyrtoconic, slightly compressed shell, with prominent sinuous, irregularly spaced annulation, growth lines, and fine longitudinal costules. Body chamber with two impressions at the concave parts of the flanks and one at the convex side. Siphuncle subcentral toward the convex side of the shell, nearly tubular with orthochoanitic septal necks. No endosiphuncular and cameral deposits known.

Stratigraphic and geographic occurrence. Darriwillian; North China, Baltoscandia, and Norway.

Discussion. The systematic position of the genus was questionable since Noetling (1884), but the investigation of features of the septal neck and the connecting ring support a close relationship to Orthoceras (Kröger 2004). Ctenoceras differs from Striatocycloceras in possessing three characteristic body chamber impressions, fine reticulate elements in the ornament, and very long chambers that are longer than two ridges of the annulations.

Sweet $(1958$, p. 72$)$ mentioned a layer of "continuous non-segmental organic calcite" within the siphuncle of Ctenoceras but it is not clear whether this layer represents true endosiphuncular deposits. Even in the more apical fragments that we investigated we did not find any traces of endospihuncular or cameral deposits. Therefore, it appears that, if deposits are present in Ctenoceras, they are strongly surpressed. Ctenoceras differs from Stereospyroceras Flower, 1955 by the lack, or strongly reduced cameral and endosiphuncular deposits and the short-orthochoanitic septal necks.

\section{Ctenoceras schmidti Noetling, 1884} Figs $7 \mathrm{~A}-\mathrm{J}, 8 \mathrm{~F}$

1877 Orthoceras verticillatum. - Krause: 24.

1884 Ctenoceras schmidti Noetling: 116, pl. 16: figs 7-8, pl. 18: figs 3-5a.

2004 Ctenoceras schmidti. - Kröger: 63, text-fig. 11a

Lectotype. MB.C.9111. The original collection of Fritz Noetling, Königsberg (now Kaliningrad, Russia) and its types was lost during the World War II. Therefore, it is impossible to find any original types. However, a specimen is reposited in the collection of the MB.C. that was collected from erratics in Bromberg (now Bydgoszcz, Poland) in 1826 by A. Krause and was originally labelled by the collector as Orthoceras verticillatum v. Hagenow. Noetling (1884) explicitly synonymised only one specimen (Orthoceras verticillatum v. Hagenow, mentioned in Krause (1877, p. 24) with Ctenoceras. Because the specimen MB.C.9111 is the only specimen labelled with Orthoceras verticillatum by Krause it is designated to serve as a lectotype.

Type locality and horizon. Erratics near Bydgoszcz, Poland; Upper Grey Orthoceratite Limestone (Darriwillian).

Material. 15 specimens are stored in the collections of the TUG and the MB.C. Nine specimens have been collected at different outcrops in northern Estonia and six specimens have been collected from erratics in northern Germany and Poland (see Appendix 2).

Diagnosis. Ctenoceras with irregularly spaced annulations, with two to four annulations at a length equal to the diameter of the conch. Two or three ridges of the annulations occur between two subsequent suture lines. Apical angle between 2 and $7^{\circ}$. Adult dorso-ventral shell diameter about $17 \mathrm{~mm}$.

Description. Specimen MB.C.9097 (Fig. 7I) is the most complete fragment of Ctenoceras that is illustrated. It exhibits the general shell form that is straight in early stages and slightly bent in adult stages. The growth interval with the strongest shell flexure also produced the strongest shell expansion rate (compare Fig. 9). The apical angle of the juvenile portion is about $2^{\circ}$ only, but between a diameter of $12 \mathrm{~mm}$ and $17 \mathrm{~mm}$ the shell grows only $42 \mathrm{~mm}$ in length resulting a apical angle of $7^{\circ}$.

Specimen MB.C.9111 is a fragment that spans the interval from the most adoral chambers of an adult phragmocone to the impressions of the body chamber. It shows that the largest shell diameter of Ctenoceras schmidti occurs at the adapical part of the body chamber at about $17 \mathrm{~mm}$. 


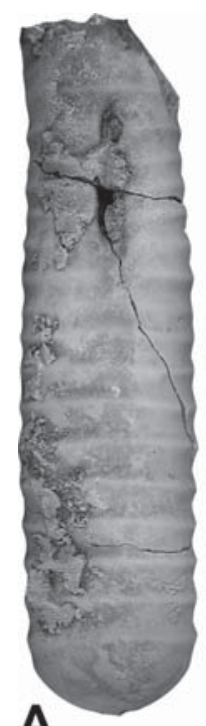

A

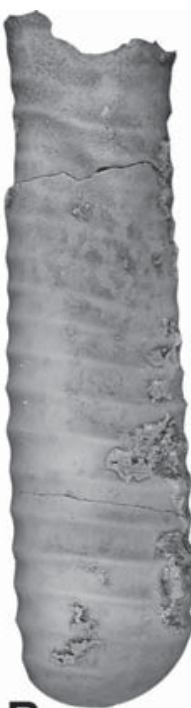

B
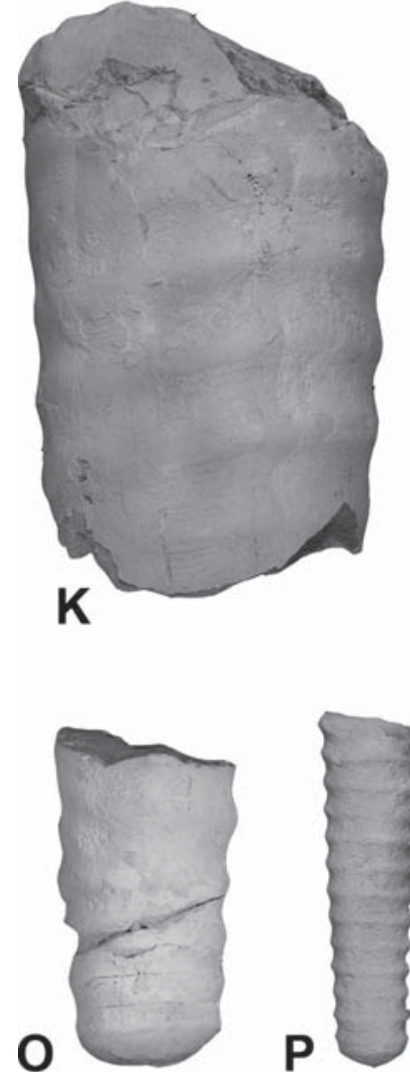

$\mathbf{P}$

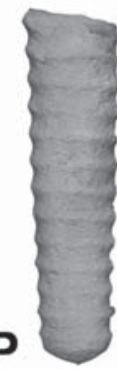

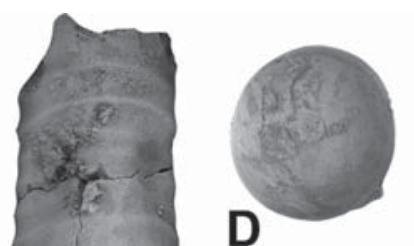

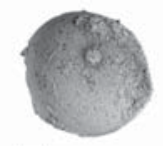

$\mathbf{E}$

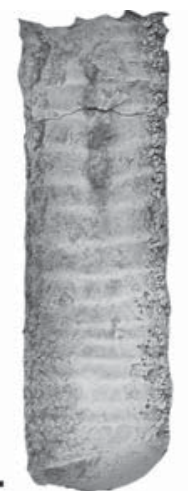

$\mathbf{F}$
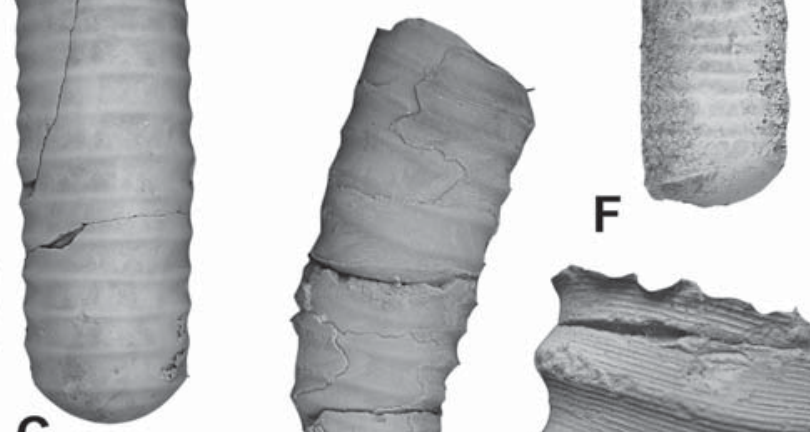

C
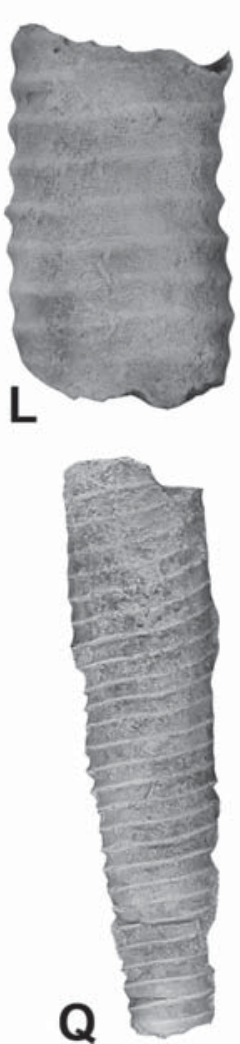

G

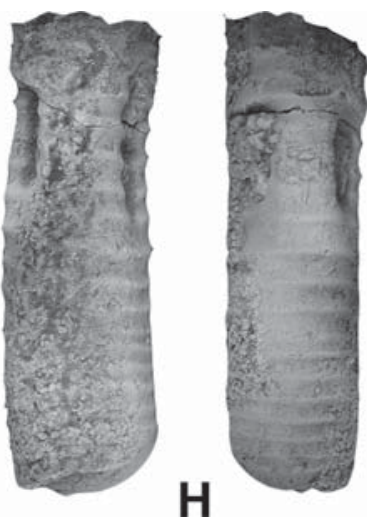

H
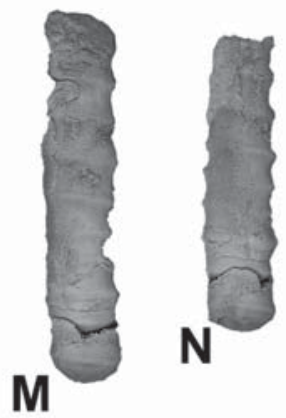

$\mathbf{S}$
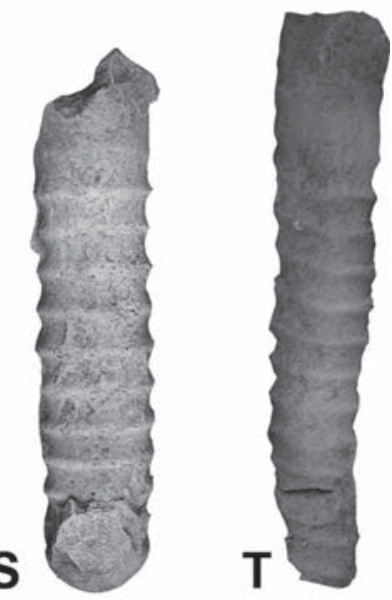

Fig. 7. Annulated Orthoceratidae of the Baltoscandic Ordovician. A-J - Ctenoceras schmidti Noetling, 1884. A-D TUG 1217/6, from Kallavere, Estonia, Aseri Regional Stage. E-H - MB.C.9111, from erratics from Bydgoszcz, Poland, coll. A. Krause, syntype. I, J - MB.C.9097, from erratics from Bydgoszcz, Poland, coll. Patrunky. H - detail showing the ornamentation with distinct transversal growth lines. K - Striatocycloceras foerstei Teichert, 1930, MB.C.9102.1, coll. D. D. Graf Keyserling, Pirgu from Mõnuste (Kirna), Estonia, Regional Stage, lateral view. L - Striatocycloceras undulostriatum (Hall, 1847), from GIT 426-10, coll. H. Stumbur, Aluvere, Estonia, Haljala Regional Stage, lateral view of an adult specimen. M, NCtenoceras sweeti n. sp., TUG 46-146, coll. K. Orviku, from Island Osmussaar, Estonia, Lasnamägi Regional Stage, holotype. $\mathbf{M}$ - lateral view, $\mathbf{N}$ - dorsal or ventral view. O - Striatocycloceras foerstei Teichert, 1930, MB.C.9102.2, coll. D. D. Graf Keyserling, from Mõnuste (Kirna), Estonia, Pirgu Regional Stage, lateral view. P - Striatocycloceras romingeri (Hall, 1847), from GIT 426-45, coll. H. Stumbur, Aluvere, Estonia, Haljala Regional Stage, dorsal or ventral view of a juvenile growth stage. Q - Striatocycloceras undulostriatum (Hall, 1847), from GIT 426-61, coll. H. Stumbur, from Paluküla, Estonia, Vormsi Regional Stage, lateral view. R-T - Striatocycloceras romingeri (Foerste, 1932). R - TUG 74-167, coll. A. Oraspõld, from Rägavere quarry, Rakvere Regional Stage, dorsal or ventral view. S - GIT 426-50, coll. S. Mägi, from Jõhvi railway, Jõhvi Regional Stage, dorsal or ventral view. T - TUG 1217-1, coll. B. Kröger, from Aluvere, Haljala Regional Stage, lateral view. All in natural size, except $\mathbf{H}(\times 3)$. 

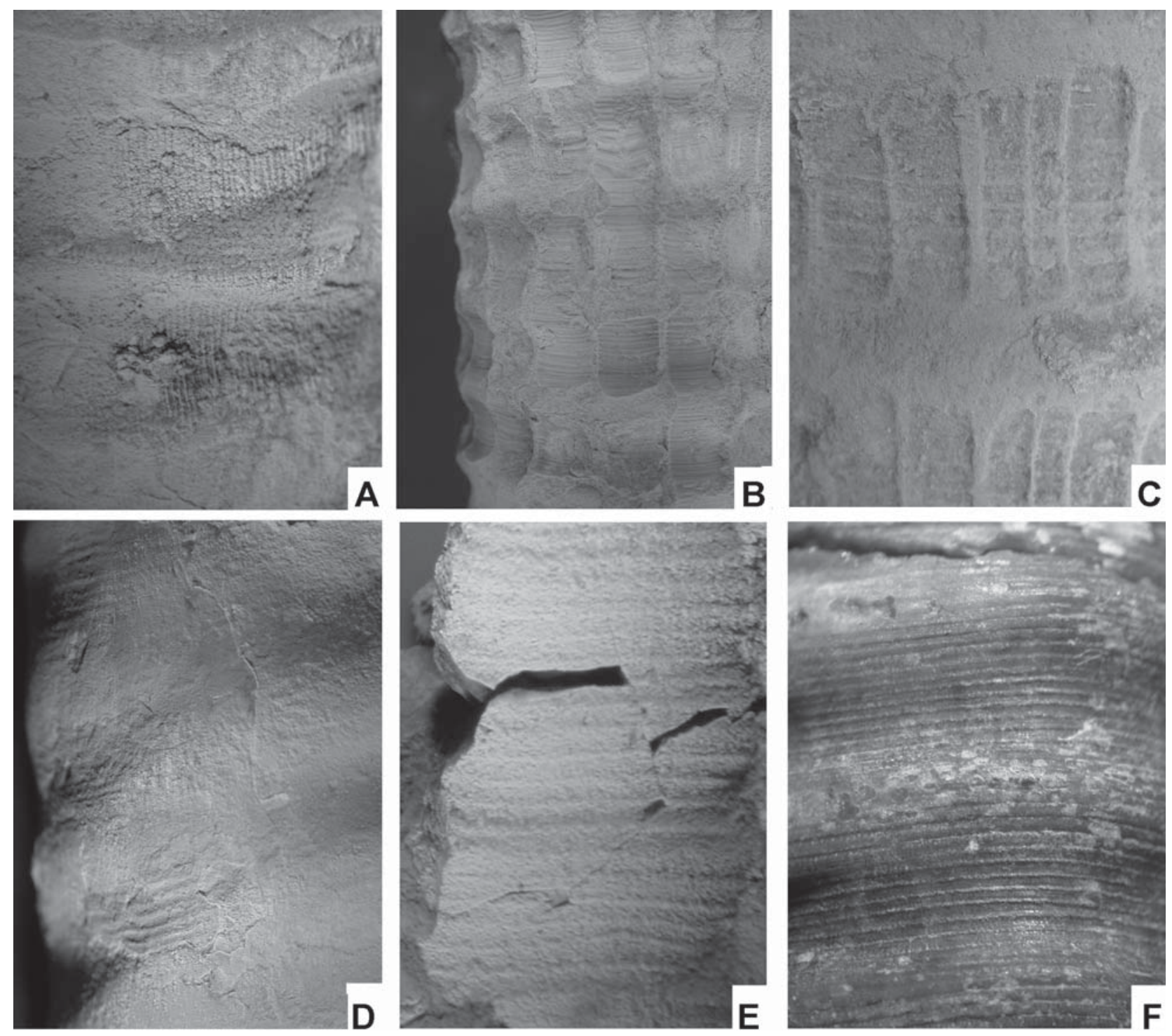

Fig. 8. Details of ornamentation of annulated orthocones of the Ordovician of Baltoscandia. A - Palaeodawsonocerina senckenbergi (Teichert, 1930), GIT 426-23, coll. R. Männil, from Saxby Nord, Island Vormsi, Estonia, $\times 5$. B - Dawsonoceras fenestratum (Eichwald, 1860), MB.C.9125, coll. Rosenberg, Porkuni, Estonia, Porkuni Regional Stage, $\times$ 3. C - Gorbyoceras textumarameum (Roemer, 1861), MB.C.9123, coll. F. Oswald, from Zawidowice near Olesnica, Poland, from Pirgu regional Stage, $\times 2.5$. D - Striatocycloceras foerstei Teichert, 1930, MB.C.9102.1, coll. D. D. Graf Keyserling, from Mõnuste (Kirna), Estonia, Pirgu Regional Stage, $\times$ 3. E - Striatocycloceras undulostriatum (Hall, 1847), MB.C.9120.1, coll. Kummerow, from erratics from near Brandenburg, northern Germany, Backstein-Limestone, Haljala Regional Stage, $\times 12$. F - Ctenoceras schmidti Noetling, 1884, MB.C.9097, coll. Patrunky, from erratics from Bydgoszcz, Poland, note the fine longitudinal striae, $\times 12$.

The diameter of body chamber decreases toward the aperture with aperture at a diameter of about $14 \mathrm{~mm}$. The distance of annulations at adult body chamber is significant larger than that of the rest of the conch.

Specimen TUG $1217 / 6$ is a complete body chamber with a length of $55 \mathrm{~mm}$. The two subquadratic impressions at the concave parts of the flanks are $7 \mathrm{~mm}$ in length and end at a distance of $10 \mathrm{~mm}$ from the aperture. The very deep longitudinal impression at the convex part of the shell is $16 \mathrm{~mm}$ long and ends at a distance of $7 \mathrm{~mm}$ from the aperture. The aperture is nearly straight, transverse, and opens like a broad funnel.
The internal characters of the species are described by Kröger (2004).

Stratigraphic and geographic occurrence. Aseri and Lasnamägi Regional Stage; northern Estonia, Öland and Upper Grey Orthoceratitic Limestone in the erratics of northern Germany and Poland.

\section{Ctenoceras sweeti n. sp.}

Figs 7M, N, 10F, G

1958 Ctenoceras sp. B. - Sweet: 74, pl. 3: fig. 1, pl. 21: fig. 8, text-fig. 10A, B. 


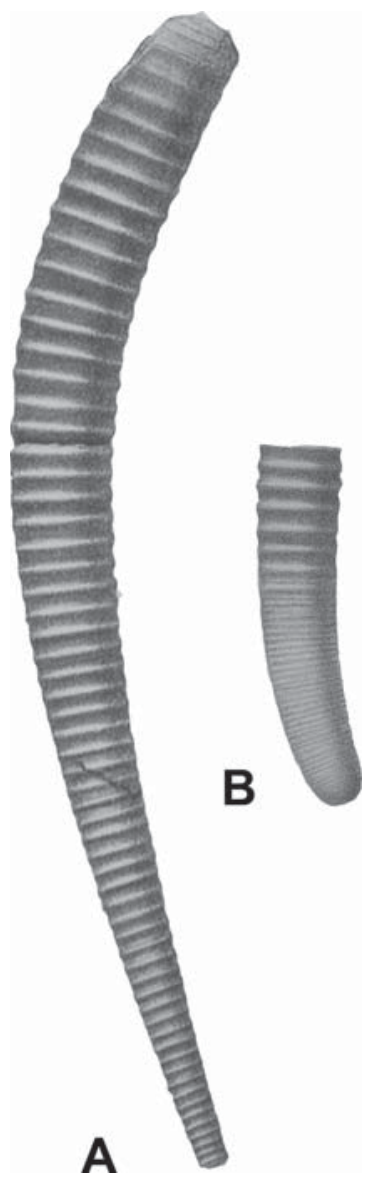

Fig. 9. Dawsonocerina cealebs (Barrande, 1866) from Barrande (1866, pl. 295: figs. 11, 17). A - natural size, $\mathbf{B}$ - size not given in original fig. Note the similarity of the general shell shape between Ctenoceras (Fig. 9I) and Dawsonocerina and the similarity between the apex shape of Dawsonoceras (Fig. 5) and Dawsonocerina.

Derivation of name. In honour of Walter C. Sweet, who revised the Middle Ordovician cephalopods of Norway (Sweet 1958) and described several new variants of Ctenoceras.

Holotype. Specimen TUG 46-146.

Type locality and horizon. Cliff at Island Osmussaar (D7, see Appendix 2); Lasnamägi Regional Stage, Darriwillian.

Material. Two specimens from the Islands Osmussaar (TUG 46-146) and Väike Pakri (TUG 1217-4), Lasnamägi Regional Stage, Dariwillian.

Diagnosis. Ctenoceras with compressed shell. Irregular, widely spaced annulations, with one to two annulations at a length equal to the diameter of the conch, each ridge of the annulations between two subsequent suture lines. Apical angle about $1^{\circ}$. Siphuncular diameter $1 / 6^{\text {th }}$ of shell diameter.

Description. Holotype TUG 46-146 is a fragment with an adapical diameter of $5.5 \mathrm{~mm}$, an adoral diameter of $6.5 \mathrm{~mm}$, and an entire length of $34 \mathrm{~mm}$. It consits of the last three chambers, each $2 \mathrm{~mm}$ in length, and body chamber of $28 \mathrm{~mm}$ in length. The shell cross section is compressed with a ratio between dorso-ventral and lateral diameter of 0.90 . The diameter of the septal perforation in the most adapical chamber is
$0.9 \mathrm{~mm}$. Siphuncle central. Shell annulated approximately 1.4 annulations equal to shell diameter. The entire fragment shows 10 annulations; their ridges are sharp and narrow to form a faint lobe at one side of the shell. Grooves between two successive ridges are wide. The ornament shows approximately 15 irregularly spaced growth lines within one cycle of annulations; very faint longitudinal elements are visible at the surface of the shell.

Stratigraphic and geographic occurrence. Lasnamägi Regional Stage; Estonia. Lower Chasmops Shale (equivalent to Kukruse Regional Stage, Middle to Late Ordovician); Oslo region.

Discussion. The classification of the species within Ctenoceras is indicated by the very characteristic rectangular micro-ornamentation. A similar ornamen is known only from the closely related Orthoceras. However, the classification within Ctenoceras may be seen as provisionally until the mature body chamber is known.

The specimens described above resemble specimens of Ctenoceras sp. B. in Sweet (1958) with respect to all aspects of the known shell morphology. Sweet (1958) previously stated that Ctenoceras sp. B. differs from Ctenoceras schmidti by exhibiting a larger central siphuncle, the lack of a significant shell curvature, and a reduced sinuosity of growth lines. Additionally, annulations of Ctenoceras sweeti are more widely spaced and the apical angle is smaller. Therefore, the two Estonian specimens that closely resemble the three specimens of Ctenoceras sp. B (Sweet 1958) support the erection of a new species of Ctenoceras.

\section{Striatocycloceras n. gen.}

Derivation of the name. From the Latin striatus $=$ band, stripe, because of the peculiar ornamentation.

Type species. Orthoceras undulatostriatum Hall, 1847

Diagnosis. Slender, circular or slightly compressed orthocones with asymmetrically curved septa and straight transverse or slightly oblique sutures. Sutures parallel, or nearly so, to the annulations. Annulations slightly irregularly spaced, with fine transverse ornament. Siphuncle eccentric, narrow, tubular or slightly expanded within the chambers. Septal necks orthochoanitic. Cameral and endosiphuncular deposits not known.

Included species. Leurocycloceras foerstei Teichert, 1930; Orthoceras obliquum Eichwald, 1860; Cycloceras romingeri Foerste, 1932; Orthoceras undulostriatum Hall, 1847.

Stratigraphic and geographic occurrence. Middle Ordovician to Late Ordovician; 

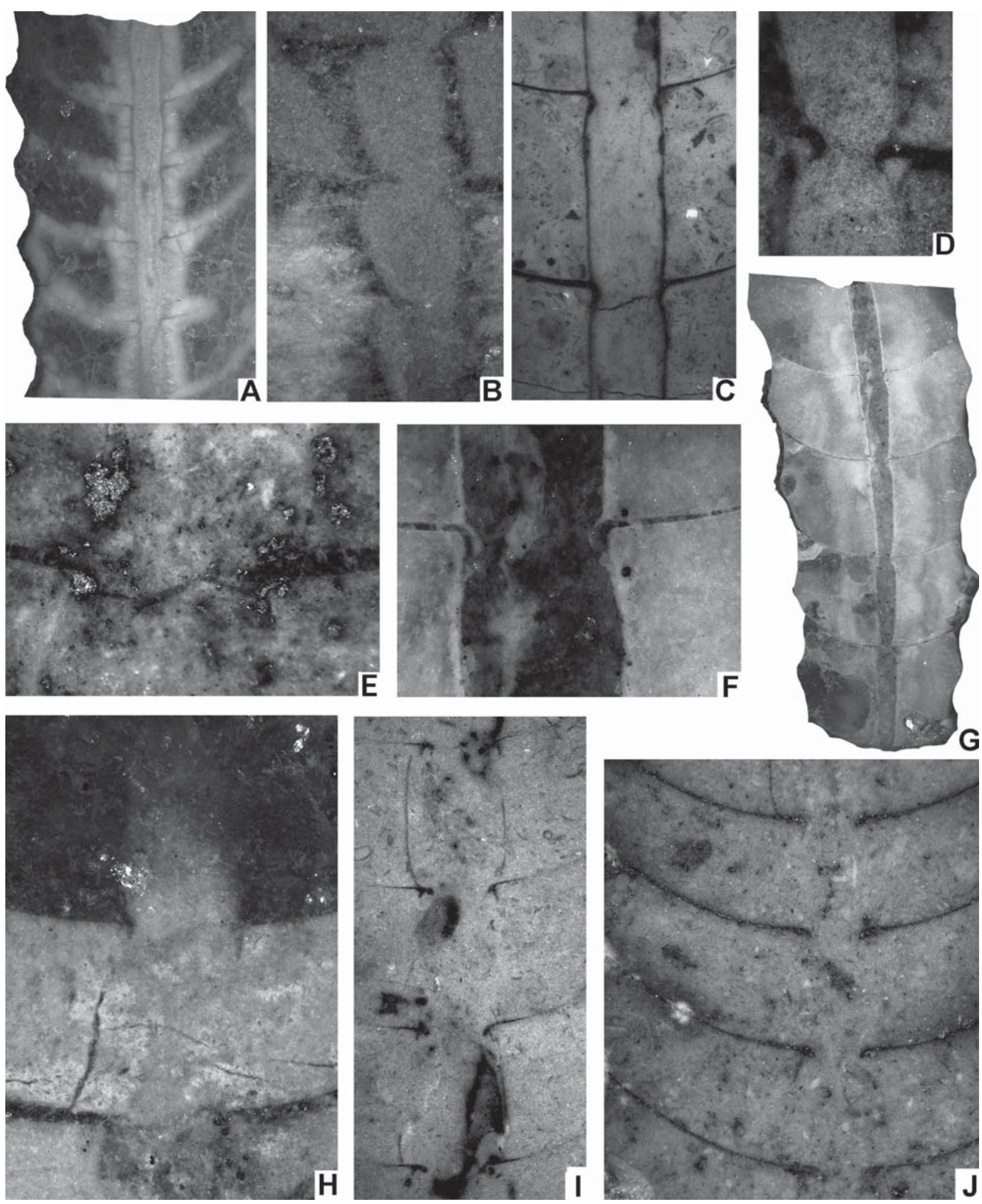

Fig. 10. Median sections of the siphuncle and septal necks of annulated orthocones from The Ordovician of Baltoscandia. A Striatocycloceras undulostriatum (Hall, 1847), GIT 426-75, coll. H. Stumbur, from Vasalemma, Estonia, Keila Regional Stage, $\times$ 5. B - Dawsonoceras fenestratum (Eichwald, 1860), TUG 1217-3, coll. B. Kröger, from Porkuni, Estonia, Porkuni Regional Stage, same specimen as in Fig. 8C, $\times 13$. C, D - Gorbyoceras textumarameum (Roemer, 1861). C - MB.C.9113, coll. Kiesow, from Zawidowice near Oleśnica, Poland, from Pirgu regional Stage, fragment of a nearly adult growth stage, $\times 5$, D MB.C.9110, coll. Damer, from Rakvere, Estland, from Pirgu regional Stage, fragment of a juvenile growth stage, $\times 10$. E Dawsonoceras sp., GIT 426-56, coll. H. Stumbur, from Paope, Estonia, Vormsi Regional Stage, fragment of juvenile growth stage, $\times$ 17. F-G - Ctenoceras sweeti n. sp., F - TUG 1217-4, coll. B. Kröger, from Island Väike Pakri, Estonia, Lasnamägi Regional Stage, $\times 25 . \mathbf{G}-$ same specimen entire fragment, $\times$ 9. H - Striatocycloceras foerstei (Teichert, 1930), GIT 426-61, coll. H. Stumbur, from Paluküla, Estonia, Vormsi Regional Stage, same specimen as in Fig.7Q, $\times 20$. I - Palaeodawsonocerina senckenbergi (Teichert, 1930), GIT 426-55, coll. H. Stumbur, Paopea, Estonia, Vormsi Regional Stage, $\times 15$. J - Dawsonoceras sp., GIT 426-54, coll. H. Stumbur, from Paope, Estonia, Vormsi Regional Stage, fragment of juvenile growth stage, $\times 17$. 
North America (Foerste 1928b; Flower 1942, 1943) and Baltoscandia (Teichert 1930).

Discussion. The designation of a new genus is necessary in order to refer to annulated orthocones with a tubular siphuncle and orthochoanitic septal necks with strongly supressed cameral and endosiphuncular deposits. The ornament of Striatocycloceras is roughly similar to some Dawsonoceratidae but differs by the latter by a fine transverse striation without longitudinal elements. Striatocycloceras differs from the surfically similar Leurocycloceras Foerste, 1928 by the lack or strongly suppressed deposits, and its much shorter septal necks. Foerste (1928a, 1932) assigned numerous Late Ordovician and Early Silurian species that were formerly, and provisionally assigned to Cycloceras McCoy, 1884, and that showed a fine transverse ornament to Leurocycloceras. A revision of Foerste's species probably will result in subsequent classification of some of those species to Striatocycloceras.

\section{Striatocycloceras undulostriatum (Hall, 1847)} Figs 7L, 8E, 10A

1847 Orthoceras undulostriatum Hall: 202, pl. 43 : fig. 7.

1850 Orthoceratites undulostriatus. - d'Orbigny: p. 3.

1855 Orthoceras undulostriatum. - Emmons: 150.

1858 Orthoceras undulostriatum. - Salter: 375, pl.13: figs 25, 26.

1915 Orthoceras undulostriatum. - Bassler, p. 918.

1928b Cycloceras undulostriatum. - Foerste: 176, pl. 40: figs $1 \mathrm{~A}-\mathrm{D}$.

1932 Cycloceras sp. - Foerste: 87, pl. 12: figs 3-4.

Holotype. AMNH 804, figured in Hall (1847).

Type locality and horizon. Middleville, New York, USA; Trenton Limestone Formation, Late Ordovician.

Material. 29 specimens in the collections of the GIT and the MB.C. The majority of the specimens have been collected at different outcrops in northern Estonia. One specimen has been collected from erratics at the island of Hiiumaa and one specimen was collected from erratics near Brandenburg in Germany.

Diagnosis. Slightly curved, slightly compressed Striatocycloceras with very low apical angle of approximately $2^{\circ}$. Adult dorsoventral diameter approximately more than $30 \mathrm{~mm}$, with four to six annulations at a distance that equates the corresponding shell diameter in adult. Annulations slightly oblique, irregularly spaced, with faint lobe at the side in opposition of the siphuncle. Distinct growth lines, 10-12 per cycle of annulations, one or two cycles of annulations per chamber. Suture lines run slightly oblique in relation to annulations forming a slight sinus at the side opposite to the siphuncle. Siphuncle subcentral. Short, orthochoanitic septal neck.

Description. Apical angle of fragments vary between $3^{\circ}$ to virtually tubular; smaller fragments show higher apical angles. The maximum shell diameter is $30 \mathrm{~mm}$ in specimen GIT 426-52 and $25 \mathrm{~mm}$ in specimen TUG 426-80 with. Both show a cycle of annulations spaced by $7 \mathrm{~mm}$. They are almost directly transverse, slightly oblique and flexed toward the convex side, with a lobe at the side of the shell that is opposite to the siphuncle. Annulations irregularly spaced with four to six annulations at a length equal to the diameter of the conch. There is a striking tendency that fragments with large shell diameters display relatively narrower annulations. Grooves of annulations widely spaced and rounded, ridges sharply edged. Growth lines run parallel to the annulations with 10-12 striae between two subsequent ridges ornament the annulated shell. Conch slightly bent with siphuncle subcentral on the external (convex) side. Length of one chamber corresponds with one or two annulations. Suture lines run parallel with annulations, usually at the flanks of the ridges. The siphuncle central or subcentral with diameter of $2 \mathrm{~mm}$ at a shell diameter of $21 \mathrm{~mm}$ (GIT 426-75). Connecting ring not preserved on described specimens. Septal necks are suborthochoanitic (Fig. 10A).

Stratigraphic and geographic occurrence. Backstein Limestone (Haljala Regional Stage, Idavere Regional Substage) in the erratics of northern Germany; Lasnamägi, Haljala, Keila, Oandu, Nabala and Vormsi Regional Stages, Estonia; Black River and Trenton Formation in North America (Foerste 1928a, b), Middle to Late Ordovician.

Discussion. Foerste (1928b) re-described the four specimens illustrated by Hall (1847) as Orthoceras undulostriatum. These four specimens, however, give no information as to the position of the siphuncle or the shape of the septal necks. However, the dimension, the shape of the conch, and the pattern of ornamentation of these specimens are identical to that found in sediments of the same age in Baltoscandia, giving the evidence to assign the Baltoscandic specimens to Striatocycloceras undulostriatum. Striatocycloceras undulostriatum is the most common annulated orthoceridan in the Late Ordovician limestones of Estonia. However, the preservation of these species is usually rather poor. The moulds of phragmocone and body chamber are often secondarily deformed and remains of the siphuncle are scarce. Nevertheless, the species is easy to identify by its narrow, oblique and irregularly spaced transverse annulations that lack any longitudinal elements. 


\section{Striatocycloceras obliquum (Eichwald, 1860)}

Figs 7K, O, 8D, 11

1860 Orthoceras obliquum Eichwald: 1209, pl. 49: fig.7.

1879 Orthoceras obliquum. - Dewitz: 34.

1880 Orthoceras obliquum. - Dewitz: 170.

1930 Orthoceras obliquum. - Teichert: 270, 278.

Holotype. At collection of KIG, illustrated in Eichwald (1860).

Type locality and horizon. Mõnuste (Kirna), West Estonia; Nabala Regional Stage, Saunja Formation or Vormsi Regional Stage, Kõrgessaare Formation (questionable), Late Ordovician.

Material. Two specimens in the collections of the MB.C., both collected by F. Damer 1876 at Mõnuste (Kirna) (MB.C.9102) and Odulema (MB.C.9108) West Estonia, from the Nabala Regional Stage, Late Ordovician.

Diagnosis. Straight, slightly compressed Striatocycloceras with high apical angle of approximately $10^{\circ}$. Six, irregularly spaced smooth annulations at a distance that equates the corresponding shell diameter in adult, with three annulations in juvenile specimens, respectively. Annulations slightly oblique toward growth direction with slight lateral sinus, with approximately 10 growth lines per annulation. One suture line at every groove of the annulation, annulations slightly oblique toward sutures.

Description. A portion of the recrystallized shell of specimen MB.C.9102 is preserved. The fragment of the body chamber displays a maximum diameter of $36 \mathrm{~mm}$, showing prominent growth lines with distances of approximately $0.7 \mathrm{~mm}$ (Fig. 8D), very similar to that of Striatocycloceras undulostriatum. Annulations of body chamber spaced at a distance of $8 \mathrm{~mm}$, describe a slight sinus at the flanks. Body chamber cross section nearly circular.

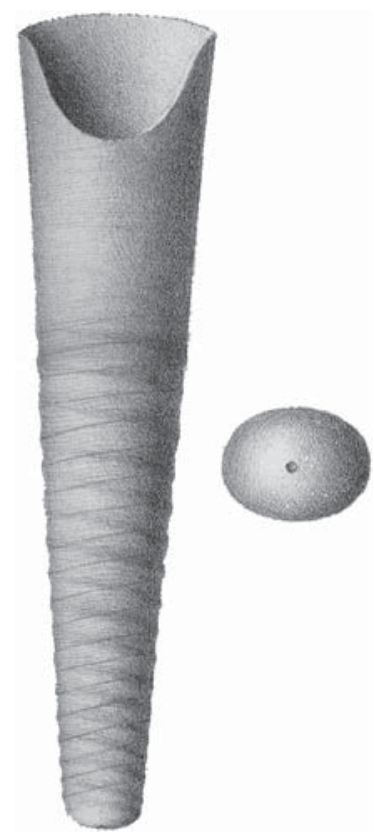

Fig. 11. Striatocycloceras obliquum (Eichwald, 1860), original illustration of Eichwald (1860: Pl. 49: Fig. 7) $\times 0.5$ )
Stratigraphic and geographic occurrence. Nabala Regional Stage, Late Ordovician; Estonia.

Discussion. No internal characters are preserved in the two specimens. However, because of the overall similarity of the species with Striatocycloceras the species is classified within the genus. The phragmocone of the species is easy to distinguish from other species of Striatocycloceras because of its comparatively high apical angle and its smooth undulations. Even the subtubular adult body chamber shows a higher apical angle than other Striatocycloceras that have been described. Teichert (1930) mentioned the similarity between $S$. foerstei and $S$. obliquum. Teichert distinguishes between $S$. foerstei and S. obliquum with regard to the occurrence of a fine transversal striation that he did not find at S. foerstei, and with regard to the compressed cross-section. The sutures in S. foerstei are not oblique toward the annulations.

\section{Striatocycloceras foerstei Teichert, 1930}

Figs 7Q, 10H

1858 Orthoceras arcuolyratum Schmidt: 196 [nom. nud.]. 1916 Orthoceras arcuolyratum. - Twenhofel: 298.

1930 Leurocycloceras foerstei Teichert: 278, pl. 6: figs 13-16. 1962 Leurocycloceras foerstei. - Balashov: 110, pl. 48: fig. 3

Holoty pe. SMF XI 358a, figured in Teichert (1930).

Type locality and horizon. Lyckholm (Saaremõisa), West Estonia; Vormsi Regional Stage, Late Ordovician.

Material. One specimen in the collection of the GIT (GIT 426-61), three specimens are in the collection of the SMF (SMF XI 358a, b, c).

Diag no sis. Straight Striatocycloceras with circular cross-section and medium apical angle of approximately $8^{\circ}$. Seven irregularly spaced annulations at a distance that equates the corresponding shell diameter. Acute annulations slightly oblique toward growth direction with slight lateral sinus, with approximately 10 growth lines per annulation. One suture line at every groove of the annulation, sutures and annulations run parallel. Siphuncle central. Short orthochoanitic septal necks.

Description. The single fragment GIT 426-61 has a length of $56 \mathrm{~mm}$, with minimum diameter of $8 \mathrm{~mm}$ and a maximum diameter of $14 \mathrm{~mm}$. Shell diagenetically compressed. Annulation oblique toward growth axis, describing a slight lateral lobe, irregularly spaced. Interspaces between annulations are wide and smooth, and the annulation saddles are acute. Six to seven annulations occur at a distance equal to cross-section diameter. Approximately 10 faint growth lines are seen between the annulations. Siphuncle central or subcentral with diameter of $1 \mathrm{~mm}$ at shell di- 
ameter of $7 \mathrm{~mm}$. Septal necks are suborthochoanitic (Fig. 10H).

Stratigraphic and geographic occurre nce. Nabala and Vormsi Regional Stage, Late Ordovician; in Estonia, Ashgillian, Late Ordovician; Podolia, Ukraine, and Siberian Platform, Russia (Balashov 1962).

Discussion. Teichert (1930) distinguished between $S$. foerstei and S. obliquum with regard to the occurrence of a fine transversal striation that he did not find at $S$. foerstei. However, the material from Lyckholm, Estonia, that Teichert investigated is rather poorly preserved and by high probability the fine striation of $S$. obliquum is not preserved at these specimens. For distinction between $S$. obliquum and $S$. foerstei, see above.

\section{Striatocycloceras romingeri (Foerste, 1932)} Fig. 7P, R-T

1932 Cycloceras romingeri Foerste: 89, pl. 12: fig. 6a, b. Holotype. UMPC 2831, figured in (Foerste 1932).

Type locality and horizon. St, Joseph Island, Lake Huron, Ontario, Canada, Black River Formation, Late Ordovician

Material. Seven specimens in the collections of the TUG, specimens GIT 426-44, -45, -46 from Aluvere), Haljala Regional Stage (Idavere Substage) specimens GIT 426-50, -50a from the Jõhvi railway outcrop, late Haljala Regional Stage (Jõhvi Substage), specimen GIT 426-84 from Oandu river outcrop, Keila Regional Stage, and specimen TUG 74-167 from a quarry south of Rägavere, Rakvere Regional Stage, all Late Ordovician.

Diagnosis. Slightly curved, slightly compressed Striatocycloceras with very low apical angle of approximately $1^{\circ}$. Adult dorsoventral diameter approximately $10 \mathrm{~mm}$, with four to five annulations at a distance that equate to the corresponding shell diameter in adult. Annulations straight, irregularly spaced, with conspicuous lobe at the side in opposition of the siphuncle. Coarse growth lines, about five to seven per cycle of annulations. One suture line at every groove of the annulation, with parallel sutures and annulations. Siphuncle central.

Description. Four specimens are fragments of body chambers with maximum diameter of $12 \mathrm{~mm}$ and minimum diameter of $9 \mathrm{~mm}$. Only specimen GIT 426-50 preserves parts of the phragmocone with the most apical chamber that displays a height of $3 \mathrm{~mm}$ at shell diameter of $10 \mathrm{~mm}$. Siphuncle slightly eccentric with diameter of approximately $1 \mathrm{~mm}$. Shell not preserved in the fragments, but remains of details of the growth lines visible on steinkerns showing a distance of about 5-7 per cycle of annulations. Annulations of body chamber spaced with a distance of 3-4 $\mathrm{mm}$ and describe a conspicuous sinus at side opposite to siphuncle. Most adapical annulations of adults very shallow and without sharp ridges. Cross sections of body chambers in all specimens slightly compressed. Body chamber appears slightly bulged in mid-length position. Grooves of annulations smooth and widely spaced, ridges sharp and narrow at top. Siphuncle central or subcentral with diameter of $1 \mathrm{~mm}$ at shell diameter of $7 \mathrm{~mm}$ (GIT 426-61). Connecting ring not preserved on described specimens.

Stratigraphic and geographic occurrence. Black River Regional Stage; North America (Foerste 1932). Haljala, Keila, and Rakvere Regional Stages (early Late Ordovician); Estonia.

Discussion. The distinctive lobe of the annulation resembles that of Striatocycloceras undulostriatum, but in $S$. romingeri the lobe is more accentuated and the annulations are narrower spaced. Additionally, compared with other Striatocycloceras, $S$. romingeri reaches only small adult sizes. No remains of the siphuncle and siphuncular necks are known, but the typical irregular ornamentation and the spacing of the septa indicate that the species must be assigned to Striatocycloceras. A specimen assigned by Evans (1993b, p. 6, pl.6: fig. 8) to Anaspyroceras with doubt from the Caradocian of Ireland shows characters of shell shape and surface that are very similar to Striatocycloceras. However, the internal characters of the specimen are not known.

\section{Family Dawsonoceratidae Flower, 1962}

Emended diagnosis. Annulated orthocones with slender, central to subcentral, tubular or moderately expanded siphuncle. Septal necks very short and can vary between achoanitic, suborthochoanitic, or very short cyrtochoanitic in some developed species. Shell ornamented with a reticulate pattern of growth lines and fine longitudinal raised lines, or with transverse festoons. Apical shell large, without cicatrix, without initial constriction, apex blunt, annulated or smooth, transverse or longitudinal ornamentation may occur. Incipient annulosiphuncular deposits, and mural cameral deposits are known.

Genera included. Metaspyroceras Foerste, 1932; Anaspyroceras Shimizu and Obata, 1935; Dawsonoceras, Hyatt, 1884; Dawsonocerina Horný, 1956; Calocyrtocerina Chen, 1981.

Stratigraphic and geographic occurrence. Late Ordovician to Late Silurian; North America, Baltoscandia, Czech Republic, Podolia, Siberia, China, Australia (e.g. Foerste 1928a, b; Flower 1946; Teichert and Glenister 1953; Wilson 1961; Horný 1956; Zhuravleva 1961; Miagkova 1967; Chen et al. 1981). 
Discussion. It is problematic to refer to the genus Dawsonoceras for many paleontologists because allegedly one has to refer to the rather poorly known Orthoceras annulatum Sowerby, 1816 that was chosen by Hyatt (1884) for the type. However, Hyatt's type does not belong to Orthoceras annulatum Sowerby, 1816. Foerste (1928), when reviewed some of the specimens of Hyatt (1884), showed that Hyatt's type specimen differs significantly from the originals of Sowerby. Therefore, he referred to Hyatt's Dawsonoceras type specimen as Dawsonoceras hyatti Foerste, 1928. The external and internal characters of Dawsonoceras hyatti are well described and illustrated by Foerste (1928). Flower (1962) ignored this detail and subsequently several authors (e.g. Dzik 1984; Evans 1994) did not refer to the problem. The main difference between Orthoceras annulatum Sowerby, 1816, and Dawsonoceras hyatti Foerste, 1928a, is the shape of the septal neck. In Dawsonoceras hyatti it is suborthochoanitic, in Orthoceras annulatum, Sowerby, 1816 it is short reticulate, and thus cyrtochoanitic (Evans pers. comm.). However, the septal necks are very short in both species, that it is hardly possible to make any decision on the status between suborthochoanitic and cyrtochoanitic. In a third species $O$. nodocostatum McChesney, 1861 this is well demonstrated by Flower (1962, pl. 6: fig. 3). The specimen figured by Flower shows septal necks that are so close between the tenuous boundary of suborthochoanitic to cyrtochoanitic that some necks can be evaluated as suborthochoanitic others as cyrtochoanitic in the same specimen. We evaluate these very short septal necks as typical character of Dawsonoceras and as characteristic feature of the Dawsonoceratidae and in general.

The apices of Dawsonoceras barrandei Horný, 1956, and from Dawsonocerina caelebs (Barrande, 1866) are known and show very peculiar features that could prove as a character that defines the family Dawsonoceratidae (Figs 5, 6C). Unfortunately, neither the apex of D. hyatti, nor that of O.annulatum is known, but it is highly probable that the apices of both species are very similar to the known ones of D. barrandei, and D. caelebs.

Consequently, Dawsonoceras needs an emendation and by this emendation the definition of the Dawsonoceratidae is affected. We emended the genus in order to include $O$. annulatum, $D$. hyatti, and $O$. nodocostatum (see below). This causes an inconsistency within the statetment below that cyrtochoanitic septal necks in orthoceri- dans are linked to apices with a cicatrix. However, we believe that the septal neck of Dawsonoceras is very peculiar because it is extremely short. Thus, the variation between $D$. hyatti and $O$. annulatum is minimal, but because it is directly at the tenuous border between suborthochoanitic and cyrtochoanitic, this variation causes confusion in an unequivocal phylogenetic classification. Here we are confronted with the limits of the merits of the cladistic method. A minimal variation, or a minimal difference in the evaluation of feature would switch Dawsonoceras and the entire Dawsonoceratidae in the outgroup. Here we designated the septal necks of Dawsonoceras as suborthochoanitic because the cyrtochoanitc septal necks of some species of Dawsonoceras are regarded as an advanced and irregular feature. We know that this weakness in the character designation can only be resolved by future investigation of additional (e.g. apex) characters.

The genera Anaspyroceras Shimizu \& Obata, 1935 and Metaspyroceras Foerste, 1932 are assigned to the Dawsonoceratidae herein. The type of Anaspyroceras is Orthoceras anellus Conrad, 1843 , a species that is rather poorly known. Foerste (1928b) re-investigated the holotype of Orthoceras anellus and characterised the ornamentation as follows: "The surface of the shell is ornamented by numerous minute filiform vertical raised lines, of which 9 occur in a width of $1 \mathrm{~mm}$ " (Foerste 1928b, p. 179). This is similar to Dawsonocerina. Also the spacing of the chambers and annulations, as well as the position of the suture lines, with regard to the annulation are similar. Flower (1943, p. 115) stated that: "Study of a specimen in the collections of the University of Cincinnati Museum revealed the presence of straight septal necks in the species, but failed to show connecting rings. The genus can, then, be used for orthochoanitic conchs of the aspect of Spyroceras". To our knowledge, the only known illustrated septal necks of Anaspyroceras are that of $A$. williamsi Flower, 1943. Flower (1943, p. 142) noted: "The siphuncle is central or nearly so, perfectly tubular, with very short septal necks". Sweet (1964, p. K230) also emphasized that the necks in Anaspyroceras are "short". Although, the initial description of the family Dawsonoceratidae of Flower (1962) emphasizes the "short recumbent" septal necks and largely tubular siphuncular segments, we explicitly expand the family diagnosis herein, in order to include not only tubular, or slightly expanded but also the strongly expanded segments of Daw- 
sonoceras fenestratum. In contrast to Flower (1962) and Sweet (1964) our emphasis is not on the recumbent septal necks, but on the short septal necks, because in short septal necks it is often very difficult to decide if a septal neck is short orthochoanitic or suborthochoanitic. The closely related genus Metaspyroceras Foerste, 1932 differs only by a different pattern of annulation from Anaspyroceras. Thus, Metaspyroceras must be assigned to the Dawsonoceratidae, too.

The apex of known Dawsonoceratidae is very characteristic. It is straight or bent and annulated (see Figs 5, 6C, 9; Barrande 1868, pl. 295: figs 16-18; Chen et al. 1981, pl. 7: figs 1-12), and always shows a flat, blunt beginning. Therefore, the key features for the Dawsonoceratidae are the large blunt apex and the very short septal necks.

It is noteworthy to add some corrections regarding the Early Devonian Orthoceras pseudocalamiteum Barrande, 1866 at this point. This species is assigned to Anaspyroceras by Ristedt (1968), Serpagli \& Gnoli (1977), Gnoli \& Serpagli (1991), and Gnoli \& Histon (1998), but it is defined as the type of Calorthoceras Chen, 1981 by Chen etal. (1981). Chen et al. define the genus by surface characters only, therefore, leaving some doubt about its eligibility and and placement into a family. However, the illustration of the apex characters by Ristedt (1968), and Fig. $5 \mathrm{~A}$ and of the characters of the siphuncular necks, show that Orthoceras pseudocalamiteum has orthochoanitic septal necks and a small, straight blunt, not constricted apex that lacks a cicatrix. Therefore, Orthoceras pseudocalamiteum clearly represents a genus that is closely related to Kionoceras, and different from Anaspyroceras. Thus, the erection of the genus Calorthoceras by Chen et al. (1981) is fully supported and $\mathrm{Ca}$ lorthoceras must be assigned to the Orthoceratidae.

\section{Palaeodawsonocerina n. gen.}

Type species. Spyroceras senckenbergi Teichert, 1930.

Diag no sis. Straight or slightly cyrtoconic, circular or subcircular shell, with prominent, narrowly spaced annulations, growth lines, and numerous subordinate filiform longitudinally raised lines, producing a fine reticulate pattern. Siphuncle central or slightly eccentric, slightly expanded, with achoanitic to very short orthochoanitic septal necks. Apex blunt, slightly cyrtoconic, annulated.

Stratigraphic and geographic occurrence. Haljala, Keila, Nabala, Vormsi and Pirgu Regional Stages (Late Ordovician); Estonia,
Ashgillian; erratics of northern Poland (Dzik 1984).

Discussion. The ornament of Palaeodawsonocerina resembles Dawsonocerina caelebs (Barrande, 1874) from the Ludlowian of the Barrandium, but differs from the latter in a siphuncle that is in a more central position, narrower and bulged outward in the chambers. Currently, only Palaeodawsonocerina senckenbergi is assigned to the genus. However, some of the species assigned to Spyroceras and Anaspyroceras by Foerste (1928a, b, c, 1932) and Wilson (1961) probably belong to Palaeodawsonocerina because of their surface characters, which are very similar, but their siphuncular features are inadequately known.

The specimen figured by Dzik (1984, pl. 35: fig. 5, text-fig. 48a) must be assigned to Palaeodawsonocerina, although representing a different species than senckenbergi. Therefore, this specimen represents a second known species of $\mathrm{Pa}$ laeodawsonocerina.

Barrande (1868, pl. 277: figs 11-13) figured an Orthoceras obscurum that occurs in the Ashgillian of the Barrandium (Marek 1999). The ornamentation of Orthoceras obscurum resembles that of Palaeodawsonoceras, but the internal features are not known. Possibly this species is also a representative of Palaeodawsonoceras.

\section{Palaeodawsonocerina senckenbergi (Teichert, 1930)}

Figs $8 \mathrm{~A}, 10 \mathrm{I}, 12 \mathrm{D}, \mathrm{E}$

1932 Spyroceras senckenbergi Teichert: 280, pl. 5: figs 3, 4. 1956 Spyroceras saxbyense Stumbur: 180, pl. 1: fig. 1.

n 1984 Spyroceras senckenbergi. - Dzik: 122, 125, pl. 35: fig. 5, text-figs $48 \mathrm{a}, 49.20$.

1991 Gorbyoceras? senckenbergi. - Kiselev: 92, pl. 1: fig. 2.

Holoty pe. SMF IX, 426a, figured in Teichert (1932).

Type locality and horizon. Lyckholm, Estonia; Lyckholm stage (= Nabala, Vormsi, and Pirgu Regional Stage), Late Ordovician.

Material. 39 specimens from the Keila, Nabala and Vormsi Regional Stage of Estonia.

Diagn osis. Straight, slightly compressed with very low apical angle of approximately $1^{\circ}-2^{\circ}$. Adult dorsoventral diameter approximately $25 \mathrm{~mm}$, with five to six annulations at a distance that equates to the corresponding shell diameter in adult specimens. Annulations straight or very slightly oblique toward the growth direction and regularly spaced. Very fine growth lines, about 50 per cycle of annulations. Very fine longitudinal striae or raised lines, about five to seven per $\mathrm{mm}$. Suture line at the ridges of the annulations. Parallel sutures and annulations. Siphuncle central, slightly expanded within the chambers. Septal perforation about 0.07 of the shell diametre. 


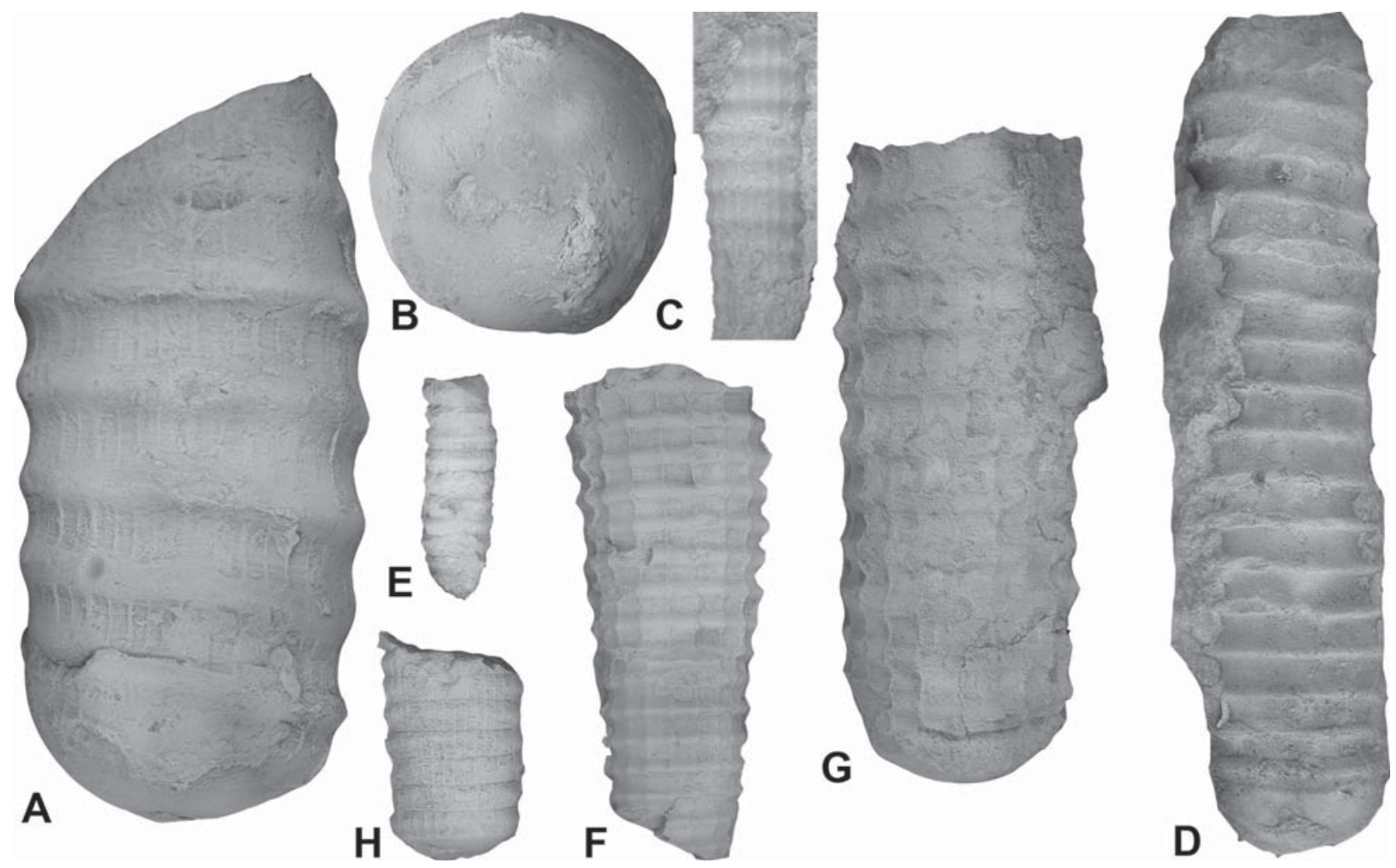

Fig. 12. Orthocone cephalopods with reticulate ornamentation from the Ordovician of Baltoscandia. A, B -Gorbyoceras textumarameum (Roemer, 1861), MB.C.9100, coll. F. Oswald, from Zawidowice near Olesnica, Poland, from Pirgu regional Stage. $\mathbf{A}$ - Lateral view of adult body chamber. B - cross section of the second youngest chamber. C - Dawsonoceras fenestratum (Eichwald, 1860), TUG 1217-2, coll. B. Kröger, from Porkuni, Estonia, Porkuni Regional Stage, fragment of juvenile growth stage. D-E - Palaeodawsonocerina senckenbergi (Teichert, 1930). D - GIT 426-23, coll. R. Männil, from Saxby nord, Island Vormsi, Estonia, ventral view of the adult body chamber. E - GIT 426-78, from Kiikla quarry, Estonia, Keila Regional Stage, fragment of juvenile growth stage. F, G - Dawsonoceras fenestratum (Eichwald, 1860). F - TUG 1217/7, sine locus, Siuge Member Porkuni Regional Stage. G - MB.C.9125, coll. Rosenberg, Porkuni, Estonia, Porkuni Regional Stage, adult body chamber. H - Dawsonoceras sp., GIT 426-56, coll. H. Stumbur, from Paope, Estonia, Vormsi Regional Stage, fragment of juvenile growth stage, note the narrow longitudinal striation. All in natural size.

Description. Teichert (1930, pl. 5: fig. 3) figured a fragment of an adult body chamber that shows that the aperture of the adult Palaeodawsonocerina senckenbergi is constricted, with flattened ridges of the annulations, and with enhanced spaces between the most adapertural annulations. The shell maximum diameter of this fragment measures $23 \mathrm{~mm}$. The maximum diameter of all known fragments $(25 \mathrm{~mm})$ was seen in specimen GIT 426-23. Its body chamber length measures $95 \mathrm{~mm}$, with a diameter of $24 \mathrm{~mm}$ at the last chamber, showing that the adult body chamber is almost tubular. The specimen's siphuncle diameter is about $2 \mathrm{~mm}$ at the last chamber.

Siphuncle diameter of the juvenile fragment GIT 426-64 (at $4 \mathrm{~mm}$ cross section diameter) is approximately $0.3 \mathrm{~mm}$. The septal perforation does not show septal necks at this diameter, and the septum is achoanitic. Median sections of specimens GIT 426-25, -61, and -63 with shell diameters $16 \mathrm{~mm}, 15 \mathrm{~mm}$, and $12 \mathrm{~mm}$, respectively, exhibit siphuncular diameter of $0.06-0.07$ of the respective diameters. Chamber height is one forth of shell diameter. Specimen GIT 426-55 shows remains of the expanded connecting ring (Fig 10I).

The shell is ornamented with annulations. They exhibit narrowly rounded ridges and widely rounded grooves of about four to six, equal to shell diameter. Annulation of shell parts of more adult specimens is strikingly narrower than in smaller fragments of juveniles. Several dozens of very narrow, transversal growth lines between two successive ridges of annulations can be seen. Very fine longitudinal elements built by narrowly rounded ridges, approximately five to seven per millimeter.

Stratigraphic and geographic occurrence. Keila to Pirgu Regional Stage; Estonia.

Discussion. The specimen figured by Dzik (1984) and assigned to Spyroceras senckenbergi differs significantly in ornamentation from the holotype figured by Teichert (1930). The longitu- 
dinal, as well as the transversal striae are more narrowly spaced in the latter.

\section{Dawsonoceras Hyatt, 1884}

Type species. Orthoceras annulatum Sowerby, 1816.

Emended diagnosis. Slender, circular or slightly compressed orthocones with symmetrically curved septa and straight transverse sutures. Sutures parallel to the annulations in each groove of the annulations. Annulations regularly spaced, with fine transverse ornament, or growth lines. Growth lines in some species festooned. In some species longitudinal ridges that may form nodes at the ridges of the annulations. Siphuncle subcentral in early growth stages, central in late growth stages, narrow, but expanded within the chambers. Septal necks short suborthochoanitic to achoanitic, in advanced forms short reticulate. Incipient annulosiphuncular deposits, and mural cameral deposits are known.

Stratigraphic and geographic occurrence. Late Ordovician (Vormsi Regional Stage) to Late Silurian; worldwide.

Discussion. Dawsonoceras shows a high variability in ornamentation. However, the characteristic ornamentation of Dawsonoceras is the festooned growth line. This growth line is a result of the interference between longitudinal and transversal elements of the ornamentation. The apex characters of Dawsonoceras are known from Dawsonoceras barrandei Horný, 1956 (Fig. 5); it is large, blunt, bowl-shaped, transversely ornamented and slightly bent. The septal necks of $D$. hyatti are suborthochoanitic (compare Foerste 1928b).

The genus diagnosis is emended in order to emphasize the short septal neck that may vary between the designations "achoanitic", "suborthochoanitic", "cyrtochoanitic" even within one fragment. Consequently, it is very difficult to provide a proper designation of the character status of the septal neck. Therefore, a minimal variation in septal neck shape also may cause a different designation of the septal neck shape and the variation within the genus appears larger than it actualy is.

The type of the genus is $O$. annulatum Sowerby, 1816, by original designation of Hyatt (1884). Foerste (1928a) mentioned that the specimens that Hyatt referred to were not identical with $O$. annulatum. He designated the species $D$. hyatti Foerste (1928a) as younger objective synonym for the specimens of Hyatt (1884). However, herein we follow the opinion of Flower (1962) and many subsequent workers to refer to $O$. annulatum as type species. With our emended diagnosis $O$. annulatum and $D$. hyatti must be regarded as member of Dawsonoceras.

\section{Dawsonoceras fenestratum (Eichwald, 1860)}

Figs 8B, 10B, 12C, F, G

1858 Orthoceras calamiteum Portlock, 1843. - Schmidt: 197 [sic].

1860 Cycloceras fenestratum Eichwald: 1231, pl. 48: fig. 14a, b.

1880 Orthoceras funiforme Angelin: 2, pl. 7: figs 18-20.

1889 Orthoceras funiforme. - Rüdiger: 59.

1889 Cycloceras fenestratum. - Rüdiger: 59.

1962 Cedarvilleoceras porkunense Balashov \& Zhuravleva: pl. 13: figs 9, 10 [nom. nud.].

1984 Cedarvilleoceras porkunense. - Dzik: 125, textfig. 49.21 .

1988 Calorthoceras (Hornyoceras) lineatum. - Kiselev: 81, text-fig. 3.

1989 Cedarvilleoceras fenestratum. - Kiselev: 65.

1989 Cedarvilleoceras porkunense. - Kiselev: 65.

1990 Cedarvilleoceras fenestratum. - Kiselev et al.: 46, 62, pl. 10: fig. 4.

1990 Cedarvilleoceras porkunense. - Kiselev et al.: 46, 62, pl. 10: fig. 1.

1991 Cedarvilleoceras fenestratum. - Kiselev: 87, pl. 2: fig. 2.

Lectotype. KIG LGI coll. \# 1/1076, figured in Eichwald (1860).

Type locality and horizon. Mõnuste (Kirna), West Estonia. At the type locality of the lectotype the Saunja Formation, Nabala Regional Stage, to Kõrgessaare Formation, Vormsi Regional Stage, Late Ordovician, crops out, but the lectotype by high probability represents an erratic element of Porkuni Regional Stage collected by Eichwald.

Material. Six specimens of different growth stages from the Siuge Member (Porkuni Regional Stage) of northern Estonia at TUG and MB.C.

Diagnosis. Dawsonoceras with an apical angle of $<10^{\circ}$ in juvenile stages. Tubular adult living chamber of approximately $25 \mathrm{~mm}$ in diameter. Five to six annulations at distance equal to shell diameter. Approximately, 20 longitudinal striae around the shell circumference, approximately fifteen growth lines or transverse striae per cycle of annulations. Septal necks achoanitic. Siphuncle subcentral, expanded within the chambers.

Description. Fragment MB.C.9125 (Fig. 12G) of an adult body chamber has a diameter of $25 \mathrm{~mm}$. Fragment is slightly bended at adoral portion and last septum. Maximum length of fragment $70 \mathrm{~mm}$ from last septum to adoral end, with eleven ridges of annulations, twenty-two longitudinal ridges, about twenty transversal striae between two ridges of the annulations. Transverse striae show pattern of festoons between reticulate ornament of transverse and longitudinal ridges. The last septum is slightly asymmetric. Siphuncle subcentrally position, $2.5 \mathrm{~mm}$ in diameter.

Phragmocone fragment TUG 1217/7 (Fig. 12F) with adoral diameter of $14 \mathrm{~mm}$ has an adapical diameter of $12 \mathrm{~mm}$ and a length of $30 \mathrm{~mm}$. The conch was depressed during taphonomy. Ornament with six ridges of annulations at length equal to shell diameter, twenty-two longitudinal ridges and about ten growth lines between two successive ridges of the annulations. 
Fragment TUG 47-728 (Fig. 12C) has $10 \mathrm{~mm}$ at its adoral end and $7 \mathrm{~mm}$ at the adapical end with a length of $27 \mathrm{~mm}$, resulting apical angle of approximately $10^{\circ}$. Six cycles of annulations occur at length equal to shell diameter, more than twenty longitudinal ridges, ridges of annulations smoother, less elevated than in more adult specimens. Chamber length equals distance of grooves of annulations. Sutures are in the midst of the grooves. Siphuncle subcentral, septal necks achoanitic in adapical part, there the septal perforation is $0.8 \mathrm{~mm}$ wide and connecting ring expands between two successive chambers to diameter of $1.5 \mathrm{~mm}$.

Stratigraphic and geographic occurrence. Porkuni Regional Stage, Late Ordovician; Baltoscandia.

Discussion. The ornament of $D$. fenestratum is very similar to that of $O$. nodocostatum McChesney, 1861. However, the internal characters of both species differ. A specimen illustrated and described by Flower (1962) as Dawsonoceras $c f$. nodocostatum from the Niagaran of Indiana displays suborthochaonitic or short cyrtochoanitic septal necks, strong mural cameral deposits, and incipient annulosiphuncular deposits. Contrarily, D. fenestratum shows achoanitic septal necks and no deposits are currently known. Therefore both species clearly can be distinguished.

O. nodocostatum McChesney, 1861 is the type of Cedarvilleoceras Shimizu \& Obata, 1935. But, Cedarvilleoceras was not accepted by Flower (1943, and following papers) and by Dzik (1984). The main argument to synonymise Cedarvilleoceras with Dawsonoceras is the similar shape of the septal neck of $O$. annulatum Sowerby, 1816 (the type of Dawsonoceras) and O. nodocostatum. It was argued above that the main character of Dawsonoceras is the very short septal neck, and that in these short septal necks small variations may have drastic consequences when designating its shape. We emended Dawsonoceras in order to include short septal necks that are at the tenuous border betwen achoanitic, suborthochoanitic or cyrtochoanitic. Consequently, we follow the opinion of Flower (1962) to synonymise Cedarvilleoceras with Dawsonoceras. Moreover, with our emendation we assign $C$. fenestratum Eichwald, 1860 to Dawsonoceras.

The synonymy list of $C$. fenestratum Eichwald, 1860 is complicated by the distinction of two species of "Cedarvilleoceras" that was proposed by Balashov \& Zhuravleva (1962) and consolidated by Kiselev et al. (1990). This opinion cannot be followed. The apical angle that is defined to be characteristic for each species can be shown to change during ontogeny. The apical portions of the shell and the adult living chamber show a very low apical angle, whereas, the juvenile growth stages are characterised by a comparatively strong increase in shell diameter. Moreover, the name Cedarvilleoceras porkunense $\mathrm{Ba}-$ lashov is a nomen nudum. The original reference is Balashov \& Zhuravleva (1962). There is no specific original reference given in Kiselev et al (1990). The only notation is that the figured specimen belongs to the collection of Z. G. Balashov. Kiselev et al. (1990) cited Cedarvilleoceras porkunense Balashov, 1960, but there is no description of the species in any of the publications of Balashov prior to 1962. The species is therefore regarded as invalid.

Spyroceras beauportense Whiteaves, 1898 and Spyroceras whitcomby Foerste, 1932 are very similar to $D$. fenestratum in surface characters. However, a synonymy of these species with $D$. fenestratum can be proofed only when the internal characters of the American species are better known.

Spyroceras perlaeve (Strand, 1934), that is very similar to D. fenestratum with respect to the surface characters, displays only 15 longitudinal striae around the circumference, its internal characters are not known.

Dawsonoceras fenestratum is very common in the Siuge Member of the Porkuni Regional Stage of northern Estonia.

\section{Dawsonoceras sp.}

Figs 10E, J, 12H

Material. Two fragments of the phragmocone from Paope, Estonia; Vormsi Regional Stage (GIT 426-54, -56).

Description. Specimen GIT 426-56 (Fig. 12H) has an adapical diameter of $18 \mathrm{~mm}$, an adoral diameter of $15 \mathrm{~mm}$, and a length of $25 \mathrm{~mm}$, with six chambers preserved. Sutures and annulations are straight Sutures are present in every groove between annulations. Annulations shallow, with ridges only $1 \mathrm{~mm}$ in height. Five annulations at length equal to shell diameter. Ornament with fine longitudinal ridges, approximately 40 occur around entire circumference, and fine transverse striae or growth lines, approximately 10 occur between two successive ridges of the annulations. Septal necks achoanitic or very short orthochoanitic. Siphuncular perforation $1 \mathrm{~mm}$ at adoral part of fragment; the siphuncle is expanded within 
chambers, maximum diameter of approximately $1.5 \mathrm{~mm}$ between two successive adapical chambers of the fragment. Septal necks are achoanitic.

Discussion. The general pattern of ornamentation, the shape of the septal neck, and siphuncle give evidence that these fragments belong to Dawsonoceras.

\section{Order Pseudorthocerida Flower \& Caster, 1935 Family Proteoceratidae Flower, 1962}

Diagnosis. Annulated or smooth orthocones or exogastric cyrtocones with expanded siphuncular segments and cyrtochoanitic septal necks in early growth stages, with narrower, subcylindrical segments and suborthochoanitic to orthochoanitic septal necks in late stages. Annulosiphonate or parietal, and cameral deposits occur in apical parts of mature specimens.

Discussion. Sweet (1964) assigned this family within the superfamily Pseudorthoceratoidea Flower \& Caster, 1935. However, Kröger \& Mapes (2006, in press) show that the Pseudorthocerida represent a distinct cephalopod order, that is fundamentally different from the Orthocerida with regard to the early growth stages. Neither the apex of Proteoceras Flower, 1955 , nor that of any other member of the Proteoceratidae is known at the time, leaving the cyrtochoanitic shape of the septal neck the sole evidence of the higher taxonomic position of the group. However, until now no cyrtochoanitic orthocones are known that display the typical apex of the Orthocerida that lacks a cicatrix. Thus, we follow the rule that cyrtochoanitic orthocones without massive endosiphuncular deposits must be assigned to the Pseudorthocerida until proven otherwise.

\section{Gorbyoceras Shimizu \& Obata, 1935}

Type species. Orthoceras gorbyi Miller, 1894.

Diagnosis. Slender, circular or slightly compressed orthocones with symmetrically curved septa and straight transverse sutures. Sutures parallel to the annulations in each groove of the annulations. Annulations with fine transverse ornament, or growth lines. Annulations more distinctive in adult growth stages. Distinctive irregularly spaced longitudinal ridges that may form nodes at the ridges of the annulations. Siphuncle subcentral, expanded in early growth stages, with short cyrtochoanitic septal necks, nearly tubular in later growth stages, with suborthochoanitic septal necks. Endosiphuncular and cameral deposits not known.

Stratigraphic and geographic occurrence. Chazyan to Richmondian; North America (Flower 1943), Caradocian and Ashgillian; Ireland and Schottland (Evans 1993a, b, 1994), and Rakvere Regional Stage to Pirgu Regional Stage; Baltoscandia.

\section{Gorbyoceras textumaraneum (Roemer, 1861)}

Figs 8C, 10C, D, 12A, B

1861 Orthoceras textum-araneum Roemer: 58, pl. 7: fig. 3a, b.

1889 Orthoceras textum-araneum. - Rüdiger: 52.

1930 Spyroceras textum-araneum. - Teichert: 280, pl. 5: fig. 6.

1962 Spyroceras textum-araneum. - Balashov: 108, pl. 48: fig. 1.

1984 Gorbyoceras textumaraneum. - Dzik: 121, 125, pl. 35: fig. 4 , text-fig. 49.15 .

Lect ot ype. UWR 1464s, figured in Roemer (1861).

Type locality and horizon. Erratic boulders from Zawidowice near Oleśnica, Poland probably Sadewitzer Kalk (Pirgu Regional Stage), Late Ordovician.

Material. 17 fragments of specimens of different growth stages from erratic blocks of Rakvere and Pirgu Regional Stages from northern Germany and Poland at the collections of the MB.C.

Diagnosis. Gorbyoceras with slightly cyrtoconic adult body chamber, shell slightly compressed, and relatively large adult size of more than $40 \mathrm{~mm}$ in cross section. Slightly irregularly spaced annulations, approximately three at the distance equal to the diameter. Approximately 35 irregularly spaced longitudinal ridges around the entire circumference of the shell. Approximately 15 growth lines between two successive ridges of annulations. Sutures straight, nearly transverse, one suture at each groove of the annulations. Siphuncle eccentric in juvenile, subcentral in more adult growth stages, septal perforation approximately one tenth of the diameter of the shell.

Description. Specimen MB.C.9100 (Fig. 12A, $B)$ is a fragment of the body chamber and last chamber of phragmocone. The body chamber is slightly bent, with adoral diameter of $44 \mathrm{~mm}$. The diameter at last septum is $38 \mathrm{~mm}$, the length of the body chamber is $70 \mathrm{~mm}$. Six annulations occur at the length of the body chamber. Annulations are slightly oblique with slight lobe at convex side of shell; ridges of annulations are relatively sharp and grooves are wide and slightly irregularly spaced. Ornament with irregularly spaced, fine longitudinal ridges, about 40 of these occur around the entire circumference. Fine transversal striae or growth lines are present, about 15 occur between two successive ridges of annulations. Length of last chamber is $5 \mathrm{~mm}$, convexity of septum is $12 \mathrm{~mm}$; siphuncle slightly eccentric at convex side of flexed shell, siphuncular perforation is $4 \mathrm{~mm}$ wide.

Specimen MB.C.9113 (Fig. 10C) is a phragmocone fragment with an adoral diameter of $25 \mathrm{~mm}$, an adapical diameter of $20 \mathrm{~mm}$, and a length of $44 \mathrm{~mm}$. Seven chambers are preserved, each corresponding to one cycle of annulations. Sutures occur in ridges between annulations. Annulations are straight, slightly bent forward at side where siphuncle is closer to shell. Ornament with approximately 40 fine longitudinal ridges around curcumference; fine transverse liration is preserved only at some places of the fragment. 
The siphuncle is slightly eccentric, nearly tubular, it is slightly constricted at septal perforation. Septal perforation at adapical part of fragment is $2.3 \mathrm{~mm}$ wide, septal necks are bent suborthochoanitic, $1 \mathrm{~mm}$ in length.

Specimen MB.C.9110 (Fig. 10D) is a phragmocone fragment with an adapical diameter of $13 \mathrm{~mm}$, an adoral diameter of $15 \mathrm{~mm}$, and a length of $16 \mathrm{~mm}$. Three chambers are preserved, each corresponds with a cycle of annulations. Traces of longitudinal striation are preserved on the surface. The siphuncle is significantly eccentric and slightly expanded between chambers. The siphuncular diameter is $1.2 \mathrm{~mm}$ at septal perforation and $2.2 \mathrm{~mm}$ between two successive chambers. Septal necks are cyrtochoanitic.

Stratigraphic and geographic occurrence. Rakvere and Pirgu Regional Stages; Estonia (Teichert 1930) and from the erratics in northern Germany and Poland, Ashgillian in the Siberian Platform, Russia.

Discussion. Beneath Orthoceras textumaraneum, Roemer (1861) described a second, very similar species that is only smaller in adult size and without a flexed adult body chamber. This second species, Gorbyoceras clathratoannulatum (Roemer, 1861), was illustrated and re-described by Teichert (1930). Because no additional material and information could be provided for the latter, a new description is not necessary herein.

\section{Acknowledgements}

We are grateful to Ursula Toom (Institute of Geology at Tallinn University of Technology, Tallinn, Estonia) for assisting the search for the material of the collection of H. Stumbur and the loan of the material, to O. Vinn (Tartu) for joining us on our field trips. J. Hartmann (Hamburg) assisted at the scan microscope, J. Müller-Edzard prepared some drawings. Many thanks to K. Waggoner (USA) for her early review of the manuscript. Thanks to D. Korn for his patience during the editing process. The investigation was made possible by DFGGrant $\operatorname{Kr} 2995 / 2$ and target financed project from the Estonian Ministry of Education and Research 0182531 s03 (Environmental indicators, palaeobiology of assemblages and taphonomy in the Palaeozoic seas). The reviews of D. H. Evans (Dublin), and J. Dzik (Warsaw) helped to improve the quality of the paper significantly; we are grateful for this support.

\section{References}

Angelin, N. P. \& Lindström, G. 1880. Fragmenta Silurica a dono Caroli Henrici Wegelin. - 60 pp., Samson \& Wallin, Stockholm.

Balashov, E. G. 1962. Nautiloidei ordovika sibirskoi platformy. - 205 pp., Izdatel'stvo Leningradskogo Universiteta, St. Petersburg.
Balashov, E. G. \& Zhuravleva, F. A. 1962. Ortryad Orthoceratida. - In V. E. Ruzhencev (ed). Osnovy Paleontologii: 82-92, Izdatel'stvo Akademii Nauk SSSR, Moskva.

Barrande, J. 1865-74. Système Silurien du centre de la Bohême, I.ère partie: Recherches Paléontologiques, vol. II, Classe de Mollusques, Ordre des Céphalopodes, 1865: ser. 6, pl. 1-107; 1866: ser. 7, pl. 108-244; 1867: ser. 1, 712 pp.; 1868: ser. 8, pl. 245-350; 1870: ser. 2, 266 pp., ser. 9, pl. 351-460; 1874: ser. 3, 804 pp.; 1877: ser. 4, 742 pp., ser. 5, 743 pp., supplement 1, 297 pp., supplement 2, pl. 461-544. Prague.

Barskov, I. S. 1968. K evolutsii otryada Pseudorthoceratida (Golovonogye Mollyuski). - Vsesoyusnoe Paleontologicheskogo Obchestvo, Trudy XII sessii Vsesoyusnovo Paleontologicheskogo Obchestvo 1968: 90-97.

- 1989. Morfogenes i ekogenes paleozoiskikh tsefalopod. 160 pp., Izdatel'stvo Moskovskogo Universiteta, Moskva.

Bassler, R. S. 1915. Bibliographic index of American Ordovician and Silurian Fossils. - Bulletin of the United States National Museum 92: 1-1521.

Bruguière, J. G. 1789. Histoire naturelle des vers. vol. 1, pt.1, Encyclopedie methodique, 6, Pancoucke, Paris \& Liège: $1-757$.

Chen Jun-yuan, Liu Geng-wu \& Chen Ting-en 1981. Silurian nautiloid faunas of central and southwestern China.Memoirs of the Nanjing Institute of Geology and Palaeontology 13: 1-104.

Conrad, T. A. 1843. Observations on the Lead Bearing Limestone of Wisconsin, and descriptions of a new genus of Trilobites and fifteen new Silurian fossils. - Proceedings of the Academy of Natural Sciences of Philadelphia 1: 329-335.

Dewitz, H. 1879. Die Wohnkammer regulärer Orthoceratiten. - Sitzungsberichte der Gesellschaft der naturforschenden Freunde Berlin 1879 (3): 32-34.

- 1880. Beiträge zur Kenntnis der in den ostpreussischen Silurgeschieben vorkommenden Cephalopoden. - Schriften der physikalisch-ökonomischen Gesellschaft zu Königsberg 20: 162-180.

Dzik, J. 1984. Phylogeny of the Nautiloidea. - Palaeontologia Polonica 45: 3-203.

Emmons, E. 1855. American geology, containing a statement of the principles of the science with full illustrations of the characteristic American fossils, vol. 1, pt. 2. - 251 pp., Gray, Sprague \& Co., Albany.

Eichwald, E. 1860. Lethaea Rossica ou Paléontologie de la Russie. - 1654 pp., Schweizerbart, Stuttgart

Engeser, T. 1996. The position of the Ammonoidea within the Cephalopoda. In Landman, N. H. \& Tanabe, K. (eds). Ammonoid Paleobiology: 3-22, Plenum Press, New York.

Evans, D. H. 1993a. The cephalopod fauna of the Killey Bridge Formation (Ordovician, Ashgill), Pomeroy County Tyrome. - Irish journal of Earth Sciences 12: 155-189.

- 1993b. The cephalopod fauna of the Bardahessaigh Formation (Caradoc Series) of Pomeroy, County Tyrone. Irish Journal of Earth Sciences 13: 11-29.

- 1994. Irish Silurian cephalopods. - Irish Journal of Earth Sciences 13: 113-148.

Flower, R. H. 1939. Study of Pseudorthoceratidae. - Palaeontographica Americana 11 (10): 1-214.

- 1942. Cephalopods of the Clinton group of New York. Bulletins of American Paleontology 27 (105): 123-157.

- 1943. Studies of paleozoic Nautiloidea. I: Tissue remnants in the phragmocone of Rayonnoceras. II. Werneroceras in the Devonian of New York. III. A Ohioceras from Virginia. IV. Investigations of actinosiphonate cephalopods. V. New Ordovician cephalopods from Indiana with notes on stratigraphic problems. VI. Annulated orthoceraconic genera of Paleozoic Nautiloids. - Bulletins of American Paleontology 28 (109): 1-140.

- 1946. Ordovician cephalopods from the Cincinnati region. Part 1. - Bulletins of American Paleontology 29 (116): 3-547. 
- 1955. New Chazyan orthocones. - Journal of Paleontology 29: $808-830$.

- 1962. Notes on the Michelinoceratida. - New Mexico Institute of Mining and Technology, State Bureau of Mines and Mineral Resources, Memoir 10: $21-40$.

- 1964. Nautiloid shell morphology. - New Mexico Institute of Mining and Technology, State Bureau of Mines and Mineral Resources, Memoir 13: 1-79.

Flower, R. H. \& Caster, K. E. 1935. The cephalopod fauna of the Conewango Series of the Upper Devonian in New York and Pennsylvania. - Bulletin of American Paleontology 22 (75): 1-74.

Flower, R. H., \& Kummel, B. 1950. A classification of the Nautiloidea. - Journal of Paleontology 24: 604-616.

Foerste, A. F. 1921. Notes on Arctic Ordovician and Silurian Cephalopods, chiefly from Boothia Felix-King William Land, Bache Peninsula, and Bear Island. - Journal of the Scientific Laboratories of Denison University 19: 247-306.

- 1924. Notes on American Paleozoic cephalopods. - Denison University Bulletin, Journal of the Scientific Laboratories 20: 193-268.

- 1928a. American Arctic and Related Cephalopod. - Denison University Bulletin, Journal of the Scientific Laboratories 23: $1-110$.

- 1928b. A restudy of some of the Ordovician and Silurian cephalopods described by Hall. - Denison University Bulletin, Journal of the Scientific Laboratories 23: 173-230.

- 1928c A restudy of American orthoconic Silurian cephalopods. - Denison University Bulletin, Journal of the Scientific Laboratories 23: 236-320.

- 1932. Black River and other cephalopods from Minnesota, Wisconsin, Michigan, and Ontario (Part 1). - Journal of Scientific Laboratories of Denison University 27: 47-136.

- 1936. The cephalopods of the Maquoketa Shale of Iowa. - Journal of Scientific Laboratories of Denison University 31: 22-92.

Gnoli, M. 1982. Lower Devonian orthocone cephalopods from Iglesiente and Sulcis regions (Southwestern Sardinia). - Bollettino della Società Paleontologica Italiana 21: $73-98$.

Gnoli, M. \& Histon, K. 1998. Silurian nautiloid cephalopods from the Carnic Alps: a preliminary investigation. - Bollettino della Società Paleontologica Italiana 36: 311-330.

Gnoli, M. \& Serpagli E. 1991. Nautiloid assemblages from middle-late Silurian of Southwestern Sardinia: a proposal. - Bollettino della Società Paleontologica Italiana 30: $187-195$

Hall, J. 1847. Natural history of New York, Paleontology, vol.1, containing descriptions of the organic remains of the lower division of the New-York system (equivalent of the Lower Silurian rocks of Europe). - 338 pp., New York Geological Survey, Van Benthuysen, New York.

Horný, R. 1956. O rodu Dawsonoceras Hyatt, 1884 (Nautiloidea) ze stredoceskoho siluru. - Sborník geologickch ved, Uzitá geofyzika, Ústrední Ústav Geologick 22: 425-444.

Hyatt, A. 1883-84. Genera of fossil cephalopods. - Proceedings of the Boston Society of Natural History 22: $253-338$

Hyatt, A. 1900. Cephalopoda. In K. A. Zittel \& C. R. Eastmann (eds). Textbook of Palaeontology, Volume 1: 502-592, Macmillan \& Co., Limited, London \& New York.

Jaanusson, V. 1976. Faunal dynamics in the Middle Ordovician (Viruan) of Balto-Scandia. - In M. G. Bassett (ed). The Ordovician system. Proceedings of a Palaeontological Association symposium: 301-326, Birmingham, September 1974, University of Wales Press, Cardiff.

Kiselev, G. N. 1971. Embryonalnye rakoviny siluryskikh Michelinoceratin. - Voprosy Paleontologii 6: 3-17.
- 1975. The Structure of the initial portions of the shell in some Silurian geisonotseratids (Orthocerida). - Paleontological Journal 4: 20-23.

- 1988. Hornyoceras - novy podrod silurskikh ortotseratoidei. - Vestnik Leningradskogo Universiteta, seria 7, 3 (21): $81-83$.

- 1989. Tsefalopody silura pribaltiki. Novy podrod siluryskikh ortotseratoidei. - Vestnik Leningradskogo Universiteta, seria 7, 1 (7): 81-83.

- 1991. Revizia pozdneordovikskikh i siluryskikh tsefalopod pribaltiki iz kollektsii E. J. Eichwalda. - Bjulleten' Moskovskogo Obchestvo Ispytatelei Prirody, Geologia 66 (4): 85-101.

Kiselev, G. N., Sinicyna, I. N., Isakar, M. A., Mironova, M. G. \& Saladzius, V. J., 1990: Atlas mollyuskov verchnevo ordovika i silura severo-zapada Vostochno Evropeiskoi platformy. - 80 pp. Izdat'elstvo Leningradskogo Universiteta, Leningrad.

Krause, A. 1877: Die Fauna der sogenannten Beyrichienoder Choneten-Kalke des norddeutschen Diluviums. Zeitschrift der deutschen geologischen Gesellschaft 12: 15-49.

Kröger, B. 2003: The size of the siphuncle in cephalopod evolution. - Senckenbergiana lethaea 83: 39-52.

- 2004: Revision of Middle Ordovician orthoceratacean nautiloids from Baltoscandia. - Acta Palaeontologica Polonica 49: 57-74.

- 2006a: The classification of orthoceridan cephalopods- a forgotten perspective. - In Cephalopods present and Past, extended abstracts, in press.

- 2006b: Early growth stages of Arenigian Baltoscandic Orthocerida (Mollusca, Cephalopoda). - Lethaia, in press.

Kröger, B., \& Mapes, R. H. 2004: Lower Carboniferous (Chesterian) embryonic orthoceratid nautiloids. - Journal of Paleontology 78: 560-573.

- 2005: Carboniferous actinoceridans (Nautiloidea, Cephalopoda) - A new perspective. - Journal of Paleontology, in press.

Kröger, B. and Mutvei, H. 2005: Nautiloids with multiple paired muscle scars from Early - Middle Ordovician of Baltoscandia. - Its bearing for taxonomic and phylogenetic reconstructions. - Palaeontology 48: 781-791.

Kuhn, O. 1940: Paläozoologie in Tabellen. - 50 pp., Fischer Verlag, Jena.

Meidla, T. \& Ainsaar, L. 2004: On the Ordovician System in Estonia. - In O. Hints \& C. R. Ainsaar (eds). WOGOGOB-2004 Conference Materials: 107-110, Tartu University Press, Tartu.

McChesney, J. H. 1861: Descriptions of new species of fossils, from the Paleozoic rocks of the Western United States. Transactions of the Chicago Academy of Sciences 1: $1-76$.

Marek, J. 1999: Ordovician cephalopods of the Prague basin (Barrandian area, Czech Republik): a review. - Acta Universitatis Carolinae, Geologica 43: 413-416.

Männil, R. 1990: The Ordovician of Estonia. - In D. Kaljo, \& H. Nestor (eds). Field meeting Estonia 1990. An Excursion Guidebook: 11-26, Estonian Acadamy of Science, Tallinn.

Miagkova, E. I. 1967: Siluriyskie nautiloidei Sibirskoi platformy. - 56 pp., Izdat'elstvo „Nauka“, Moskva.

Miller, S. A. 1894. Palaeontology. - Indiana Department of Geology and Natural Resources Annual Report 18: 257-356.

McCoy, F. 1844: A Synopsis of the Characters of the Carboniferous Limestone Fossils of Ireland. - 207 pp., University Press, Dublin.

Neben, W. \& Krueger, H. H. 1971: Fossilien ordovizischer Geschiebe. - Staringia 1: 1-50.

- 1973: Fossilien ordovizischer und silurischer Geschiebe. Staringia 2: 51-109. 
Noetling, F. 1884: Beiträge zur Kenntniss der Cephalopoden aus Silurgeschieben der Provinz Ost-Preussen. - Jahrbuch der Königlich Preussischen Geologischen Landesanstalt und Bergakademie zu Berlin 1883: 101-135.

Orbigny, A. D. d' 1850: Prodrome de Paléontologie stratigraphique universelle des animaux mollusques \& rayonées faisant suite au cours élémentaire de paléontologie et géologie stratigraphique. vol. I, 394 pp., vol. II. 427 pp., Paris.

Portlock, J. E. 1843: Report on the geology of the county of Londonderry and parts of Tyrone and Fermanagh. 784 pp., Dublin.

Riedel, R. 1975: Die Ordnung des Lebendigen. Systembedingungen der Evolution. - 372 pp., Pail Parey, Hamburg \& Berlin.

Ristedt, H. 1968: Zur Revision der Orthoceratidae. - Akademie der Wissenschaften und Literatur in Mainz, Abhandlungen der mathematisch-naturwissenschaftlichen Klasse, 1968: $211-287$.

- 1971: Zum Bau der Orthoceratiden Cephalopoden. - Palaeontographica, A 137: 155-195.

Roemer, C. F. 1861: Die fossile Fauna der silurischen Diluvial-Geschiebe von Sadewitz bei Oels in Niederschlesien - Eine palaeontologische Monographie. - 79 pp., Druck Robert Nischkowsky, Breslau/Wroclaw.

Rõõmusoks, A. 1970: Stratigrafia Viruskoj i Harjuskoj Serij (Ordovik) Severnoj Estonii, I. - 343 pp., Izdat'elstvo "Valgus", Tallinn.

- 1983: Eesti aluspõhja geoloogia. - 224 pp., Izdat'elstvo "Valgus", Tallinn.

Rüdiger, H. 1889: Ueber die Silur-Cephalopoden aus den mecklenburgischen Diluvialgeschieben. 86 pp., InauguralDissertation, Philosophische Fakultät, Universität Rostock, Michael \& Schuster, Güstrow.

Salter, J. W. 1858: Fossils of the Durness Limesone. In Murchison's On the Succession of the Older Rocks in the Northernmost Counties of Scotland; with some Observations on the Orkney and Shetland Islands. - The Quarterly Journal of the Geological Society of London 15: 353-418.

Schlotheim, E. F. Freiherr von 1813. Beiträge zur Naturgeschichte der Versteinerungen in geognostischer Hinsicht. - Leonhard's Taschenbuch für die gesammte Mineralogie, 7: 3-134.

- 1820: Die Petrefactenkunde auf ihrem jetzigen Standpunkte, durch die Beschreibung seiner Sammlung versteinerter und fossiler Überreste des Tier- und Planzenreichs der Vorwelt erläutert, I-LXII. - 437 pp., Becker Verlag, Gotha.

Schmidt, F. 1858: Untersuchungen über die Silurische Formation von Ehstland, Nord-Livland und Ösel. - Archiv für die Naturkunde Liv-, Ehst- und Kurlands, 1. Serie (Mineralogische Wissenschaften, nebst Chemie, Physik und Erdbeschreibung) 2: 1-248.

- 1861: Nachträge und Berichtigungen zu den Untersuchungen über die Silurische Formation von Ehstland, NordLivland und Ösel. - Archiv für die Naturkunde Liv-, Ehst- und Kurlands, 1. Serie (Mineralogische Wissenschaften, nebst Chemie, Physik und Erdbeschreibung) 2: 465-474.

Serpagli, E. \& Gnoli, M. 1977: Upper Silurian cephalopods from southwestern Sardiania. - Bollettino della Società Paleontologica Italiana 16: 153-196.
Shimansky, V. N. 1962: Obshaya kharakteristika golovonogikh. In V. E. Ruzhencev (ed). Osnovy Paleontologii: 15-72. Izdat'elstvo Akademii Nauk SSSR, Moskva.

Shimizu, S. \& Obata, T. 1935: New genera of Gotlandian and Ordovician nautiloids. - Shanghai Science Institute Journal, sect. 2, 2: 1-10.

Sowerby, J. 1812-18: The Mineral Conchology of Great Britain; or Coloured Figures and Descriptions of those Remains of Testaceous Animals or Shells which have been Preserved at Various Times and Depths in the Earth. volume 2. - 251 pp., London.

Strand, T. 1934: The Upper Ordovician Cephalopods of the Oslo Area. - Norsk Geologisk Tidskrift 14: 1-118.

Stumbur, H. 1956: O nautiloideakh kokhilaskogo jarusa (Verkhniy Ordovik Pribaltiki). - Tartu Riikliku Ülikooli Toimetised 42: 176-185.

Sweet, W. C. 1958: The Middle Ordovician of the Oslo region of Norway. 10. Nautiloid cephalopods. - Norsk Geologisk Tidsskrift 3: $1-178$.

- 1964: Nautiloidea-Orthocerida. - In R. C. Moore (ed). Treatise on Invertebrate Paleontology, Part K, Mollusca 3: K216-K261, Geological Society of America and the University of Kansas Press.

Teichert, C. 1930: Die Cephalopoden-Fauna der LyckholmStufe des Ostbalticums. - Paläontologische Zeitschrift 12: 264-312.

- 1933: Der Bau der actinoceroiden Cephalopoden. - Palaeontographica, A 77: 111- 230.

Teichert, C. \& Glenister, B. F. 1953: Ordovician and Silurian cephalopods from Tasmania. - Bulletins of American Paleontology 34 (100): 1-54.

Teichert, C. \& Moore, R. C. 1964: Classification and stratigraphic distribution. - In R. C. Moore (ed). Treatise on Invertebrate Paleontology, Part $\mathrm{K}$, Mollusca 3: K94-K106, Geological Society of America and the University of Kansas Press.

Troedsson, G. T. 1926: On the Middle and Upper Ordovician faunas of northern Greenland, I. Cephalopods. - Meddelelser om Grønland 71: 1-157.

- 1931: Studies on Baltic fossil cephalopods. I. On the nautiloid genus Orthoceras. - Lund Universitets Arsskrift, N. F., Avd. 2, 27 (16): 1-36.

Twenhofel, W. H. 1916: The silurian and high ordovician Strata of Estonia, Russia and their faunas. - Bulletin of the Museum of Comparative Zoölogy at Harvard College 56, 3. Geology; Series 10, 3. Shaler Memorial Series 2: 290-354.

Webby, B. D. 1995: Towards an Ordovician time scale. In J. D. Cooper, M. L. Droser, \& S. C. Finney (eds) Ordovician Odyssey: Short Papers for the Seventh International Symposium on the Ordovician System: 5-10, SEPM Pacific Section, Fullerton, CA.

Whiteaves, J. F. 1885-98; On some additional or imperfectly understood fossils from the Hamilton formation of Ontario, with a revised list of the species therefrom. - Geological Survey of Canada, Contributions to Canadian Paleontology, 1 (5): 360-436.

Wilson, A. E. 1961: Cephalopoda of the Ottawa Formation of the Ottawa-St. Lawrence Lowland. - Bulletin of the Geological Survey of Canada 67: 1-106.

Zhuravleva, F. A. 1961: Nekotorye paleozoiskie nautiloidei Podolii. - Paleontologicheskii Zhurnal 1961 (4): 55-59. 


\section{Appendix}

\section{Apex and septal neck characters of orthocones}

\begin{tabular}{|c|c|c|c|c|c|c|}
\hline Nr. & genus & epoch & reference & $\begin{array}{l}\text { cicatrix } \\
\text { present }\end{array}$ & septal neck shape & $\begin{array}{l}\text { \# of species with } \\
\text { apical characters } \\
\text { known }\end{array}$ \\
\hline 1 & Archigeisonoceras & Ordovician & Kröger (2006a) & no & orthochoanitic & 1 \\
\hline 2 & Arionoceras & Silurian & Serpagli an Gnoli (1977) & no & orthochoanitic & 2 \\
\hline 3 & Caliceras & Silurian & Kiselev (1985) & no & orthochoanitic & 2 \\
\hline 4 & Calocyrtocerina & Silurian & Chen et al. (1981) & no & orthochoanitic & 1 \\
\hline 5 & Dawsonoceras & Ordovician & herein & no & achoanitic & 1 \\
\hline 6 & Cyrtocycloceras & Silurian & Chen et al. (1981) & no & orthochoanitic & 1 \\
\hline 7 & Dawsonocerina & Silurian & herein & no & achoanitic & 1 \\
\hline 8 & Eridites & Silurian & Mjagkova (1967) & no & achoanitic & 2 \\
\hline 9 & Geisonoceras & Silurian & Ristedt (1971) & no & orthochoanitic & 4 \\
\hline 10 & Geisonoceras & Silurian & Kiselev (1975) & no & orthochoanitic & \\
\hline 11 & Hedstroemoceras & Ordovician & Kröger (2006a) & no & orthochoanitic & 1 \\
\hline 12 & Kionoceras & Silurian & Ristedt (1971) & no & orthochoanitic & 2 \\
\hline 13 & Merocycloceras & Silurian & Ristedt (1971) & no & orthochoanitic & 1 \\
\hline 14 & Merocycloceras & Silurian & Gnoli \& Serpagli (1991) & no & orthochoanitic & 1 \\
\hline 15 & Michelinoceras & Silurian & Kiselev (1971) & no & orthochoanitic & 4 \\
\hline 16 & Michelinoceras & Silurian & Ristedt (1971) & no & orthochoanitic & 4 \\
\hline 17 & $\begin{array}{l}\text { Orthoceras } \\
\text { (sensu lato) }\end{array}$ & Sil./Dev. & Ristedt (1971) & no & orthochoanitic & 18 \\
\hline 18 & $\begin{array}{l}\text { Sphaerorthoceras } \\
\text { (sensu lato) }\end{array}$ & Devonian & Gnoli (1982) & no & orthochoanitic & 4 \\
\hline 19 & $\begin{array}{l}\text { Sphaerorthoceras } \\
\text { (sensu lato) }\end{array}$ & Silurian & Serpagli \& Gnoli (1977) & no & orthochoanitic & 10 \\
\hline 20 & $\begin{array}{l}\text { Sphaerorthoceras } \\
\text { (sensu lato) }\end{array}$ & Sil./Dev. & Ristedt (1971) & no & orthochoanitic & 39 \\
\hline 21 & Spyroceras & Silurian & Ristedt (1971) & no & orthochoanitic & 1 \\
\hline 22 & Temperoceras & Silurian & Kiselev (1975) & no & orthochoanitic & 1 \\
\hline 23 & Campyloceras & Carboniferous & Ristedt (1971) & yes & cyrtochoanitic & 1 \\
\hline 24 & Dolorthoceras & Carboniferous & Ristedt (1971) & yes & cyrtochoanitic & 5 \\
\hline 25 & Dolorthoceras & Carboniferous & Kröger \& Mapes (2004) & yes & cyrtochoanitic & 1 \\
\hline 26 & Euloxoceras & Carboniferous & Kröger \& Mapes (2004) & yes & cyrtochoanitic & 1 \\
\hline 27 & Mitorthoceras & Carboniferous & Kröger \& Mapes (2004) & yes & cyrtochoanitic & 1 \\
\hline 28 & Mooreoceras & Carboniferous & Ristedt (1971) & yes & cyrtochoanitic & 1 \\
\hline 29 & Mooreoceras & Carboniferous & Kröger \& Mapes (2004) & yes & cyrtochoanitic & 2 \\
\hline 30 & Navis & Permian & Ristedt (1971) & yes & cyrtochoanitic & 1 \\
\hline 31 & $\begin{array}{l}\text { "Orthoceras" } \\
\text { (sensu lato) }\end{array}$ & Carboniferous & Ristedt (1971) & yes & cyrtochoanitic & 3 \\
\hline 32 & Pseudactinoceras & Carboniferous & Ristedt (1971) & yes & cyrtochoanitic & 2 \\
\hline 33 & Pseudocyrtoceras & Carboniferous & Ristedt (1971) & yes & cyrtochoanitic & 1 \\
\hline 34 & Pseudorthoceras & Carboniferous & Ristedt (1971) & yes & cyrtochoanitic & 5 \\
\hline 35 & Reticycloceras & Carboniferous & Ristedt (1971) & yes & cyrtochoanitic & 3 \\
\hline 36 & Reticycloceras & Carboniferous & Kröger \& Mapes (2004) & yes & cyrtochoanitic & 1 \\
\hline 37 & Ristedtoceras & Carboniferous & Kröger \& Mapes (2004) & yes & cyrtochoanitic & 1 \\
\hline 38 & Shikhanoceras & Permian & Ristedt (1971) & yes & cyrtochoanitic & 1 \\
\hline 39 & Uralorthoceras & Permian & Ristedt (1971) & yes & cyrtochoanitic & 2 \\
\hline
\end{tabular}

\section{Outcrops in northern Estonia and material}

\section{Darriwillian}

D1. Suur Pakri Pank, Island Suur Pakri, 59 $20^{\prime} 45^{\prime \prime} \mathrm{N}, 023^{\circ} 54^{\prime} 32^{\prime \prime}$ E, Aseri Regional Stage; Ctenoceras schmidti (2).

D2. Pliiku ots (Bjäràddn), Island Väike Pakri, 59 $21^{\prime} 45^{\prime \prime}$ N, $023^{\circ} 57^{\prime} 19^{\prime \prime}$ E, Lasnamägi Regional Stage; Ctenoceras schmidti (1).

D3. Kannuka at Sillamäe, $59^{\circ} 24^{\prime} 1^{\prime \prime} \mathrm{N}, 027^{\circ} 45^{\prime} 20^{\prime \prime}$ E, Aseri Regional Stage; Ctenoceras schmidti (5).

D4. Valaste Quarry, Valaste, $59^{\circ} 43^{\prime} 89^{\prime \prime}$ N, $27^{\circ} 36^{\prime} 72^{\prime \prime}$ E, Aseri Regional Stage; Ctenoceras schmidti (1).

D5. Kallavere, $59^{\circ} 48^{\prime} 64^{\prime \prime} \mathrm{N}, 25^{\circ} 03^{\prime} 25^{\prime \prime}$ E, Aseri Regional Stage; Ctenoceras schmidti (1).

D6. trench near Lüganuse quarry, $59^{\circ} 23^{\prime} 34^{\prime \prime} \mathrm{N}, 27^{\circ} 05^{\prime} 2^{\prime \prime} \mathrm{E}$, ?Lasnamägi Regional Stage; Ctenoceras schmidti (1).

D7. Island Osmussar, $59^{\circ} 28^{\prime} 94^{\prime \prime} \mathrm{N}, 23^{\circ} 37^{\prime} 80^{\prime \prime}$ E, Lasnamägi Regional Stage; Ctenoceras sweeti (1).

D8. Nehatu, W of Tallinn, 59 $26^{\prime} 8^{\prime \prime}$ N, $024^{\circ} 57^{\prime} 5^{\prime \prime}$ E, Lasnamägi Regional Stage; Striatocycloceras undulostriatum (1). Caradocian

Haljala Regional Stage

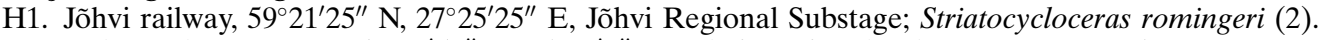

H2. Rakvere large quarry, $59^{\circ} 20^{\prime} 58^{\prime \prime}$ N, $26^{\circ} 23^{\prime} 4^{\prime \prime}$ E, Jõhvi Regional Substage; Striatocycloceras romingeri (1).

H3. Oandu river outcrop, 59 $34^{\prime} 56^{\prime \prime}$ NE 26 $6^{\circ} 23^{\prime \prime}$ E, Jõhvi Regional Substage; Striatocycloceras romingeri (1).

H4. Peetri Hill, W of Tallinn, $59^{\circ} 21^{\prime} 54^{\prime \prime}$ N, $024^{\circ} 29^{\prime} 55^{\prime \prime}$ E, Idavere Regional Substage; Striatocycloceras romingeri (1). 
H5. Aluvere quarry, southern wall, $59^{\circ} 22^{\prime} 38^{\prime \prime}$ N, $026^{\circ} 24^{\prime} 16^{\prime \prime}$ E, Aluvere Member, Jõhvi Regional Substage; Striatocycloceras romingeri (5), Striatocycloceras undulostriatum (11).

H6. Spitham (Põõsaspea), 59 $13^{\prime} 35^{\prime \prime}$ N, $023^{\circ} 31^{\prime} 12^{\prime \prime}$ E, Striatocycloceras undulostriatum (1).

H7. Sooaluse trench, NE Rakvere, 59 $24^{\prime} 25^{\prime \prime}$ N, $26^{\circ} 28^{\prime} 46^{\prime \prime}$ E, Jõhvi Regional Substage, Kahula Formation; Striatocycloceras undulostriatum (1).

Keila Regional Stage

K1. Vasalemma, 59 $14^{\prime} 18^{\prime \prime}$ N, $24^{\circ} 17^{\prime} 13^{\prime \prime}$ E, Vasalemma Formation; Striatocycloceras undulostriatum (6).

K2. Ristna cliff, W of Harju-Risti, $59^{\circ} 16^{\prime} 8^{\prime \prime}$ N, $23^{\circ} 44^{\prime} 55^{\prime \prime}$ E, Keila Formation, Kurtna Member; Striatocycloceras undulatostriatum (3).

K3. Kiikla, South of Jõhvi, 59 $16^{\prime} 48^{\prime \prime}$ N, 27 $7^{\circ} 14^{\prime} 39^{\prime \prime}$ E; Palaeodawsonoceras senckenbergi.

Oandu Stage

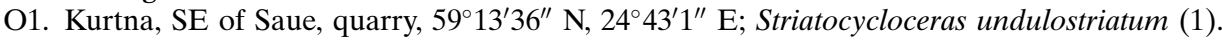

\section{Nabala Regional Stage}

N1. Tapa, $59^{\circ} 15^{\prime} 44^{\prime \prime}$ N, $25^{\circ} 57^{\prime} 22^{\prime \prime}$ E, Saunja Member; Striatocycloceras undulostriatum (1).

N2. Odulema, S of Keila, $59^{\circ} 8^{\prime} 14^{\prime \prime}$ N, $24^{\circ} 21^{\prime} 12^{\prime \prime}$ E; Striatocycloceras obliquum (1).

N3. Mõnuste (Kirna), E of Haapsalu, $58^{\circ} 53^{\prime} 26^{\prime \prime}$ N, $23^{\circ} 52^{\prime} 24^{\prime \prime}$ E; Striatocycloceras obliquum (2), Dawsonoceras sp. (1)

Vormsi Regional Stage

V1. Lehtse, Soodla river, $59^{\circ} 16^{\prime} 02^{\prime \prime} \mathrm{N}, 025^{\circ} 50^{\prime} 50^{\prime \prime} \mathrm{E}$; Striatocycloceras undulostriatum (1).

V2. Paluküla II, Island Hiiumaa, $58^{\circ} 58^{\prime} 58^{\prime \prime}$ N, 22 $48^{\prime} 20^{\prime \prime}$ E, Striatocycloceras foerstei (1), Palaeodawsonoceras senckenbergi (5).

V3. Paope, Island Hiiumaa, 58 56 $51^{\prime \prime}$ N, 22 $26^{\prime} 2^{\prime \prime}$ E; Striatocycloceras undulostriatum, Palaeodawsonoceras senckenbergi; Gorbyoceras textumaraneum.

V4. Saxby N, Island Vormsi, 59 $9^{\prime} 9^{\prime \prime}$ N, $23^{\circ} 8^{\prime} 29^{\prime \prime}$ E; 10x Palaeodawsonoceras senckenbergi (10).

V5. Kõrgessaare, Island Hiiumaa, 58 $58^{\prime} 44^{\prime \prime} \mathrm{N}, 22^{\circ} 27^{\prime} 52^{\prime \prime}$ E; Palaeodawsonoceras senckenbergi (3).

V6. Tuhala, natural carst field, S of Tallinn, $59^{\circ} 13^{\prime} 21^{\prime \prime} \mathrm{N}, 24^{\circ} 58^{\prime} 11^{\prime \prime} \mathrm{E} ; 2 \mathrm{x}$ Palaeodawsonoceras senckenbergi (2).

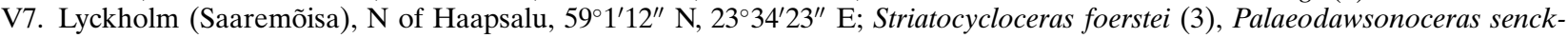
enbergi (6).

\section{Ashgillian}

Pirgu Regional Stage

P4. Niibi (Nyby), N of Haapsalu, 59 $02^{\prime} 5^{\prime \prime}$ N, $23^{\circ} 39^{\prime} 9^{\prime \prime}$ E; Palaeodawsonoceras senckenbergi (1).

Porkuni Regional Stage

Pk1. Porkuni, SW of Rakvere, $59^{\circ} 11^{\prime} 15^{\prime \prime}$ N, $026^{\circ} 11^{\prime} 15^{\prime \prime}$ E, Siuge Member, Ärina Formation; Dawsonoceras fenestratum (8). 